\title{
NOTAS BIBLIOGRAFICAS
}

\author{
Matos Moctezuma, Eduardo. Cacaxtla. Ci- \\ ticorp, México, 1987
}

Libro interesante y original sobre las renombradas pinturas murales de Cacaxtla. Organizado en dos secciones fundamentales: la primera, Algo sobre $\mathrm{Me}$ soamérica, en la cual se presentan, a grandes rasgos, las características del área mesoamericana, y la segunda, Color, Forma y Simbolismo, en donde se describen e interpretan, también de modo general, las escenas 'de los muros pintados. Complementan lo anterior, a manera de apéndice, un Análisis de los pigmentos, realizado por el Laboratoire de Conservation de la Pierre, en Laussane, Suiza, análisis necesario, pero infrecuente en los estudios acerca de pintura mural prehispánica, y un álbum de espléndidas fotografías a color hechas por Rafael Donis. Las fotos se acompañan por fragmentos de poemas tomados de Poesía náhuatl, t.2 y 3, de Ángel María Garibay.

En la primera sección el autor establece lo que es la "superárea cultural y geográfica" (p. 9) de Mesoamérica, con base en la definición de 1943 de Paul Kirchnoff, y expone los rasgos sobresalientes de los períodos cronológicos, de acuerdo con lo postulado por la arqueología tradicional; desde el Prehistórico hasta el Postclásíco.

A continuacion, Matos expresa su inconformidad con "ese panorama esta" blecido a base de estancos" (p. 16) que no corresponde, dice, a la "realidad arqueológica" (p. 16) . Por ello, propone "tres planteamientos generales (p. 16) para comprender mejor el desarrollo temporal de las sociedades mesoamericanas; así postula primero, a partir de los olmecas, una sociedad clasista "profundamente estratificada donde un sector de ella ostenta el poder economico, social, político y religioso" (p. 16). Segundo, una economía basada en la agricultura y la guerra, y tercero, a modo de conclusión lógica de los anteriores planteamientos, que "las sociedades mesoamericanas irán evolucionando con cambios cuantitativos, pero sin llegar a modificaciones más profundas que revolucionen las bases fundamentales de su desarrollo" (p. 16). En suma, Matos rechaza la aplicación de conceptos de periodización, en especial de los llamados clásico y postclásico, entendidos sobre la base de sociedades teocráticas y militaristas respectivamente. Con aparente sentido de continuidad cultural y no de ruptura como lo definen los periodos tradicionales, el autor explica la evolución de los pueblos mesoamericanos en tres etapas esenciales: la de Cazadores-Recolectores-Igualitarios, desde la llegada del hombre al continente americano hasta el descubrimiento de la agricultura; la de Sociedades-Agricolas-Igualitarias a partir de la adopción del trabajo agrícola como sustento económico primordial y hasta la presencia de aldeas permanentes, y con ellas el surgimiento de deidades relacionadas con la tierra y el agua, y... "figurillas de la fertilidad" (p. 19). En estas dos etapas "no hay grupo que controle a otro ni uno que aproveche para si el trabajo ajeno" (p. 19). La tercera etapa de las Sociedades-Agricolas-Estatales, y abarca desde tiempos olmecas hasta la llegada'de los españoles; se distingue por sus avances en técnicas de cultivo, conocimientos calendáricos y astronómicos, la aparición 
de la figura sacerdotal y, sobre todo, por el surgimiento del Estado. La economía se basa en la doble explotación de la agricultura y el tributo.

La primera sección es fundamento de la segunda; la atención del autor no se concentra en el aspecto artístico de las pinturas, sino en la interpretación antropológica y social que de ellas se deriva. Describe, con viveza, los Murales de la Batalla, ejecutados hacia 650 en el Edificio B, y a continuación los Murales del Pórtico, ejecutados un siglo después. Su descripción se apoya, en partes, en el estudio de Sonia Lombardo de Ruiz (Cacaxtla, el lugar donde muere la lluvia en la tierra, SEP, INAH, Gobierno del Estado de Tlaxcala, Instituto Tlaxcalteca de la Cultura, México, 1986). De este modo da idea del Mural de la Batalla, dividido en dos partes por una pequeña escalera, y señala el equilibrio de imágenes en ambas partes, las figuras que destacan entre los vencedores guerreros-jaguares, con "facciones características del altiplano" (p. 24), y entre los vencidos guerreros-aves "de filiación mayoide" (p. 25). Hace hincapié, de manera sucinta y general, en los rasgos que convierten las pinturas de Cacaxtla en una muestra pictórica excepcional, por su armonía y vivacidad colorística, por el dinamismo y expresividad de los guetreros, por el ritmo equilibrado de las posturas. Observa, también, algún caso de semejanza con aspectos de los murales de Bonampak y con los de Teotihuacan, $y$ destaca los valores expresivos de las figuras: la actitud heróica del jefe vencedor " 3 venado" y el padecimiento dramático de heridos y mutilados. El Mural de la Batalla, considerado por Matos como "dato arqueológico" (p. 36), lo lleva a postular que se trata de una batalla histórica; "no se trata de guerra entre sacerdotes" (p. 36), como suponen quienes consideran que el período clásico - durante el cual se realizaron las pinturas- es dominado por una sociedad teocrática, sino de una lucha de soldados "que tiende a mantener el control económico, político y social" (p. 36). Sin embargo, añade el autor, la guerra tiene también un carácter religioso-teológico "que no logra encubrir la verdadera intención económica" (p. 36). En el Mural del Pórtico, después de la descripción, Matos procede a dar cuenta de su interpretación. Aquí ve, como Sonia Lombardo de Ruiz, quien lo denomina Mural de la Fertilización de la T'ierra, al dios Tláloc asociado a los hombres-jaguares, en los muros y jambas norte, y al dios Quetzalcóatl, en relación con los hombres-águilas, en el muro y jamba sur. Y los que fueron contrarios en la Batalla, se convierten en armoniosa dualidad para propiciar el agua, la fertilidad y la cosecha de plantas de maíz. Apunta una diferencia con Lombardo; para Matos, los hombres.águilas se vinculan con Huitzilopochtli, dios solar de la guerra, y de este modo explica la dualidad Tláloc-Huitzilpochtli, que siglos más tarde encuentra en el Templo Mayor de los mexicas. A manera de comprobación usa la imagen de la barra azul con cabezas de serpiente en los extremos, que toma entre sus brazos el caballero águila de la pared sur; es la imagen previa a la xiuhcóatl azteca.

El autor concluye reiterando su oposición al mal usado concepto de sociedades teocráticas durante el período clásico, que se transforman, durante el postclásico, en sociedades militaristas; para él, a lo largo de veinticinco centurias, de los olmecas a los aztecas, las sociedades son estatales.

A manera de comentario final, me parece que Eduardo Matos hace uso de lo representado en los murales de Cacaxtla para justificar su criterio antro- 
pológico del desarrollo de las sociedades que habitaron Mesoamérica. Ciertamente, no pretende, como lo haría un crítico o historiador de arte, partir de la evidencia artística para alcanzar supuestos de identidad iconográfica. Sin embargo, no son las escenas y los símbolos que se encuentran en Cacaxtla los que apoyan la tesis de Matos; las interpretaciones que de ellas deriva son, por ahora, supuestos débilmente sustentados. Se inclina por darle a la Batalla un sentido histórico, pero no relega la posibilidad de un significado religioso; y al Pórtico le atribuye definitivamente un carácter religioso y teológico. En ambos casos, como en gran parte de la imaginería prehispánica, no existen elementos objetivos que confirmen o nieguen de modo definitivo sus interpretaciones. Estamos en el umbral de un acercamiento más yeraz a los significados de las imágenes plásticas; para ello es necesario recurrir con rigor a diversos métodos: la iconografía, la semiótica, las religiones comparadas, y hacer uso de los textos tardíos con la reserva adecuada. El estudio de Eduardo Matos es, así lo indiqué al principio de esta nota, interesante y original, aporta distinto enfoque cultural y con ello da lugar a replantearse entre muchas otras cosas, lo que se ha dicho en torno a las pinturas de Cacaxtla. Estas serán motivo de otras lecturas, de otras maneras de ver, de otras interpretaciones.

Beatriz de la Fuente

\author{
Elizabeth H. Boone, ed, \\ The Aztec Templo Mayor. \\ A Symposium at Dumbarton \\ Oaks. Dumbarton Oaks, \\ Washington, D. C, 1987 .
}

Este libro es una contribución muy importante para la interpretación de los hallazgos de las excavaciones recientes del Templo Mayor. En él se publican las contribuciones al simposio celebrado en octubre de 1983 en Dumbarton Oaks. Consta de 16 articulos, los dos últimos con discusiones y comentarios sobre los anteriores; contiene además un prefacio y un índice.

El primer artículo trata de las investigaciones hechas sobre el Templo Mayor de 1521 a 1978. La autora, Elizabeth $\mathrm{H}$. Boone, las divide en seis fases. Cada una de ellas, nos dice, puede caracterizarse "por un punto de vista, acercamiento y grado de comprensión particular" (p. 5). Por otra parte, las fuentes etnohistóricas ofrecen una información amplia sobre dicho templo; testimonio de ello es el artículo de Miguel León-Portilla. Las diversas etapas de engrandecimiento del templo, los objetos asociados al mismo y los sacrificios y celebraciones llevados a cabo en él, son el tema de su estudio.

En el tercer artículo, Augusto Molina determina las novedades en la arquitectura mexica. Dichas novedades se encuentran sólo en detalles secundarios, con dos excepciones: el uso de pilotes de madera y el empleo de un núcleo duro y compacto que pudo, con el tiempo, llevar a innovaciones importantes en las estructuras de los edificios.

Doris Heyden, en su artículo sobre el simbolismo de la cerámica del Templo Mayor, estudia principalmente dos tipos de vasijas, unas con la máscara 
de Tláloc y las otras con efigies de una deidad de la vegetación; ambas son analizadas minuciosamente.

De los partícipes en el simposio, tres trabajaron en las excavaciones del Templo Mayor. El director del proyecto, Eduardo Matos Moctezuma, se acerca al simbolismo del Templo Mayor a través de dos niveles: el de la estructura y el de la superestructura. La estructura de la sociedad mexica, cuya base era la agricultura y la guerra, se refleja en los dioses venerados en dicho templo: Tláloc y Huitzilopochtli. En cuanto a .la superestructura, que engloba las creencias sobre el cosmos, considera que para los mexicas el Templo Mayor era el centro del universo, el punto en el cual el nivel celeste y el inframundo empezaban y donde se originaban las cuatro direcciones del universo. Explica también cómo el Templo Mayor estaba relacionado íntimamente con los mitos. Por su parte, Juan Alberto Román enfoca su trabajo a la ofrenda 48 en la cual se descubrieron los restos de 42 niños. Con base en las fuentes etnohistóricas y en estudios recientes, opina que dichos niños fueron sacrificados en honor de los Tlaloques. El artículo de Carlos Javier González nos permite una mejor comprensión de las figurillas y máscaras tipo Mezcala; ejemplares de ellas fueron halladas en el Templo Mayor. Estos hallazgos arrojan luz sobre la cronología de este estilo (fines del Clásico y Posclásico), sobre su asociación con Tláloc y la fertilidad (por lo menos en el contexto del Templo Mayor) y cómo reflejan la expansión del poderío de Tenochtitlan.

El tributo y el comercio eran muy importantes en la economía mexica. Frances F. Berdan logra esclarecer su funcionamiento en la obtención de objetos de lujo. Estos últimos llegaban a Tenochtitlan por tres vías: el tributo, el comercio con lugares distantes y el intercambio en los mercados; el primero jugaba un papel menor, pues las otras dos vías eran las principales.

Johanna Broda, en su artículo, trata sobre el simbolismo del Templo Mayor y la cosmovisión mexica. Según nos dice, las ofrendas excavadas demuestran que a dicho templo se le consideraba no sólo como la montaña sagrada, sino además como la tierra misma que requería de sacrificios para contribuir con su fuerza regenerativa a la fertilidad. La fauna marina encontrada en las ofrendas sugiere que los mexicas querían evocar la presencia del mar en el Templo Mayor, pues "el mar era el símbolo de la fertilidad absoluta encarnada en el agua". (p. 223) Tanto este artículo, como el de Alfredo López Austin marcan nuevas rutas a seguir en la interpretación de los hallazgos del Templo Mayor. Este último autor realiza un análisis iconográfico de la escultura atípica del Dios del Fuego con una máscara desenterrada cerca del Templo $\mathrm{C}$ y concluye que presenta elementos del Dios del Fuego y del inframundo (el cual engloba las regiones terrestre, acuática $y$ dẹ la muerte). En el caso de esta escultura se le representó en el Mictlán con la máscara facial de 'Tláloc o sea de la muerte pero, como va a renacer, carece de las arrugas faciales típicas de Huehuetéotl. La combinación del fuego y de la muerte lo asocian asimismo con el dios patrón de la fiesta Xócotl Huetzi.

Para poder llevar a cabo el estudio de las representaciones del autosacrificio del Templo Mayor, Cecilia F. Klein las divide en dos grupos con base en su formato y su composición. El primer grupo abarca las procesiones y 
también la llamada Piedra de los Guerreros. El segundo grupo incluye relieves de una y dos figuras. La investigadora llega a la conclusión de que ambos grupos se refieren a eventos sucedidos entre el momento que un soberano era electo y cuando se le instalaba en el trono después de que había demostrado stu valor en una batalla.

Richard F. Townsend dedica su investigación princpialmente a los ritos celebrados durante la coronación de los soberanos de Tenochtitlan. En estos ritos, el Templo Mayor "era el escenario central y la piedra de toque en la secuencia de eventos" (p. 406). El autor analiza detalladamente las cuatro fases de la secuencia ritual en la toma de posición del gobernante, a saber: el retiro, la coronación, la guerra para comprobar su valentía y la confirmación.

Las lápidas con fechas localizadas en el Templo Mayor son el tema de trabajo de Emily Umberger. Dichas lápidas han ayudado a fechar las fases constructivas de dicho templo. La autora opina que la fase IV $b$ fue terminada antes de la muerte de Motecuhzoma I, a diferencia de Matos, que la fecha en el reinado de Axayácatl. Umberger establece que las lápidas conmemoran el fin y el comienzo de un ciclo calendárico: o la muerte de un gobernante y el ascenso del siguiente, pero en todos los casos conmemoran el triunfo de los mexicas, de Huitzilopochtli y el Sol.

Las reflexiones anotadas en el artículo de Esther Pasztory se refieren al papel desempeñado por los textos, la arqueología y el arte en la interpretación de los hallazgos del Templo Mayor. Otras reflexiones tratan sobre la importancia de la ideología en la organización del estado mexica y en qué grado los soberanos manipulaban dicha ideología o eran, a su vez, limitados por la misma.

H. B. Nicholson enfoca sus comentarios al problema del fechamiento de las etapas constructivas del Templo Mayor. Aconseja cautela en el uso de las lápidas con fechas, pues carecen de escenás alusivas a dichas etapas. Advierte además que la correlación entre la secuencia arquitectónica y los datos de las fuentes etnohistóricas presentan cierta problemática.

En su comentario al simposio, George Kubler divide los artículos en tres grupos: los que usan la historia para acercarse al Templo Mayor, los que versan sobre la iconografía y la ideología y los que se enfocan al estilo y la interpretación de las obras. Después de hablar brevemente sobre cada artícu10, concluye con los aspectos positivos del simposio y las interrogantes para trabajos futuros.

\title{
Nelly Gutiérrez Solana
}

\begin{abstract}
Architectural Practice in Mexico City, A Manual of Journeyman Architects of the Eighteent $b$ Century, translated, with an Introduction and Annotation by Mardith Schuetz. Tucson: University of Arizona Press, 1987.
\end{abstract}

Este libro da a conocer un documento de grandísimo interés para la historia de la arquitectura colonial. Se trata de la edición-anotada de un manuscrito 
anónimo de finales del siglo XVIII, actualmente en una colección privada estadunidense. El original, intitulado Architectura mechanica conforme la practica de esta Ciudad de México, es obra de un arquitecto todavía no identificado. Dado que hasta ahora el único texto arquitectónico colonial conocido era el del siglo XVII de Fray Andrés de San Miguel, la importancia de este nuevo documento es evidente.

El manuscrito, de 44 fojas, es un texto incompleto de apuntes con definiciones y noticias útiles de todo tipo, desde legales hasta técnicas, para arquitectos en la Nueva España. Para dar una idea del contenido, citaré sólo algunos de sus subtítulos: Varios términos que usan los maestros, Malas costumbres de este arte, Método y práctica de hacer una tasación, Examen de un arquitecto, Instrumentos y libros que ha de tener un maestro, Extracto de varios sitios con sus precios. Posiblemente su autor iba a reorganizar el texto al terminarlo. El manuscrito también incluía dibujos que desafortunadadamente faltan, aunque Schuetz pudo reconstruir dos de ellos.

La introducción y las notas aclaran muchos puntos, así que sólo voy a comentar algunos que me parecen sobresalientes. Schuetz, con toda razón, entiende que una de las aportaciones más notables de este documento está en lo que revela del ambiente cotidiano en el cual se movían los arquitectos novohispanos de la segunda mitad del siglo XVIII. Llama la atención en este sentido el orgullo del autor en su profesión: "este trabajo no mancha como no ha manchado a los Cetros y Coronas que se han empleado en la colocación de las primeras piedras de los templos". Tanto insiste en la dignidad de la arquitectura, que nos convence de lo controvertido que era este punto en aquella época. Tocante a esta cuestión, nos da la noticia de que para los arquitectos había examen "de lo blanco" y "de lo prieto". Sólo los que habían pasado el primero podían hacer tasaciones y encargarse de obras de mampostería y cantería. Es más, el autor insiste que un arquitecto, 0 "Príncipe de los Edificios", "no es menester que sea de profesión albañil, como quieren algunos, basta que sea práctico en la arquitectura, montea y cortes de cantería y que pueda rayar cualquier género de arco o de vuelta". Se queja: "la arquitectura es arte como los demás liberales pero en esta tierra se ha hecho gremio". Estamos frente a una actitud ilustrada, de libre profesionista. Este desprecio hacia las prácticas gremiales y artesanales arroja dudas sobre la hipótesis de Schuetz de que el autor era criollo. Por otra parte, los conocimientos de primera mano del oficio de arquitecto mayor indican que había ocupado ese puesto.

Los comentarios sobre las portadas amplían la visión del arquitecto como supervisor. Con toda claridad, el autor afirma que las portadas "no vienen a ser otra cosa que unos colatetales en la calie". Por lo tanto, el diseño de una portada "bien lo puede hacer cualquier pintor siendo diestro", aunque tiene que seguir las medidas y proporciones que le dé el arquitecto. El alzado o planta es trabajo de un ensamblador ("ensambladores son aquellos artífices de colaterales"). El arquitecto sólo corrige los dibujos y se entiende con el capataz de los canteros que van a llevar a cabo la obra. Sirvan estas pequeñas muestras para indicar el interés de este manuscrito.

Por fortuna, Mardith Schuetz tuvo el buen sentido de presentar el texto castellano junto con su traducción anotada, y fotografías de dos fojas origi- 
nales, así que la Arquitectura mecánica es asequible para todos los interesados en el tema. Esto es doblemente importante, ya que el manuscrito se encuentra en una colección cerrada al público.

Sólo en las ilustraciones del libro encontré algunos errores que deben señalarse. El grabado decimonónico en la p. 33 ilustra la iglesia y la plaza de Santo Domingo, no el convento, que ya estaba destruido, y ni la iglesia ni el convento pueden llamarse "home of the Inquisition". El dibujo de la Plaza Mayor de México, reproducido en la p. 66, es obra de Diego García Conde y fue criticado en su época por su mala calidad; hubiera sido mejor escoger otro. Finalmente, hubiera sido deseable que Schuetz, quien conoce mucho de bibliografía mexicana sobre arquitectura colonial, hubiera podido servirse de algunos estudios más recientes sobre los arquitectos en la ciudad de México, en especial los trabajos de Martha Fernández sobre los maestros mayores de los siglos XVI y XVII. Cierran el libro un glosario, la bibliografía y un índice.

\section{Clara Bargellini}

Gabrielle G. Palmer. Sculpture in the Kingdom of Quito Alburquerque: Univer. sity of New Mexico Press, 1987.

Todos sabemos que hacen falta estudios sobre la escultura colonial, así que da gusto ver este bello libro en el cual se presenta un panorama del desarrollo estilístico de la escultura figurativa quiteña. Inicia con las estatuas espanolas importadas durante los siglos XVI y XVII y sigue con las tallas propiamente coloniales del XVIII y principios del XIX. Para orientar al lector, sirven algunos captiulos sobre la historia general de la escultura española de la época, sobre la escultura quiteña en su conjunto y sobre la historia de la Audiencia de Quito en sus diferentes etapas. El libro termina con la exposición de una visión psicologista del desarrollo de la escultura quiteña, según la cual estas obras no sólo serían originales respecto a la producción española, sino que en su creatividad anticipan los movimientos de independencia del siglo XIX. El texto viene acompañado por una generosa selección de fotografías en color y en blanco y negro, y una bibliografía.

La autora hizo su tesis doctoral en Estados Unidos sobre el tema y su deseo, expresado en el libro, es proporcionar una introducción a la escultura quiteña que también estimule el interés por el arte colonial -entre el público norteamericano, se entiende-. Espero que logre su propósito. Para los interesados en la escultura colonial mexicana, el texto resulta a veces demasiado simple. Sin embargo, aun cuando no dé suficiente información sobre las medidas y otras características materiales de las piezas, será siempre conveniente tenerlo a mano.

Las inquietudes que esta obra suscita no se refieren tanto a la descripción cuanto al análisis de la escultura colonial, en particular la definición de estilos. La autora, una y otra vez, deja ver que concibe los estilos como entes con vida propia. No sólo habla de ellos con términos biológicos y orgánicos 
y cree que se desarrollan en sentido progresivo y a un ritmo lento y equilibrado; los estilos para ella son sujetos: "el rococó inicia un período de individualismo", êl estilo barroco "utiliza todos los recursos", etc. Confieso que encuentro desconcertante leer estas expresiones en un libro de historia del arte de 1987. Ya deberíamos de haber entendido que los estilos no existen fuera de sus manifestaciones y de nuestros discursos acerca de ellos. Además, especialmente en el caso de las condiciones de producción de la escultura colonial, el desarrollo estilístico no puede ser lineal.

Parece que la autora intuye que este tipo de discurso es problemático y expresa cierta incomodidad respecto a los análisis estilísticos, pero se siente obligada, tal vez por la historiografía del arte europeo, a hablar de los estilos en cierta secuencia. Se deja llevar, por ejemplo, hacia una extensa disquisición sobre el manierismo, sin convencernos de que esto puede ayudar a entender la escultura quiteña. En el último capítulo; busca una salida del problema con una interpretación psicológico-social, a la manera de Hauser, con apoyos en Rank, Eliade y, especialmente, en la apreciación de Germain Bazin sobre la escultura de Donatello. El arte reflejaría directamente un estado anímico de la sociedad. No me opongo a que se intente proporcionar este tipo de explicaciones, pero ciertamente es necesario fundamentarlas con más rigor y cautela. Hasta falta la ilustración de una pieza que la autora considera central para su argumento, la figurilla de una bailarina negra, hecho inexplicable en un libro tan bien ilustrado.

Si la autora reconociera que el problema no está en los análisis estilísticos - herramientas básicas del historiador del arte-, sino en un concepto de estilo como esencia independiente, hubiera podido seguir, con mucho provecho, algunos de los caminos que ella misma indica en otras partes del texto. Más de una vez declara que hacen falta estudios formales cuidadosos de las obras de los escultores quiteños más importantes. Dada su propia ca" pacidad para desarrollar este tipo de análisis, ampliamente demostrada, especialmente en sus comparaciones entre esculturas españolas y esculturas quiteñas, no entiendo por qué no los hizo. Hace tiempo Pal Kelemen, que no está citado en este libro, esbozó algunos análisis de la escultura de Quito e intentó comparaciones con esculturas coloniales latinoamericanas de otros lugares. Debemos de insistir en esa empresa. Por otra parte, a lo largo del texto, la autora menciona también aspectos iconográficos, así como algunas de las circunstancias sociales y técnicas de la producción de la escultura quiteña, y parece estar muy interesada en los entornos arquitectónicos que albergan las esculturas. Todos éstos son caminos que valdría la pena explorar con cuidado.

Además de su preocupación por los problemas estilísticos, la autora tiene un especial interés en la libre expresión artística. Desafortunadamente, tiende a transponer el concepto moderno, liberal, de la creación artística a una época muy distinta de la nuestra. Aparte la inadmisible opinión de asociar libertad de expresión con libre comercio, aparecen comentarios discutibles acerca de las intenciones que llevaron a ejecutar las obras, sin indicar cuáles eran las funciones de éstas en la vida diaria de la sociedad. Se perciben, además, ciertas confusiones respecto a la distinción entre gremio y cofradía, por ejemplo, y sobre las reformas borbónicas. Aunque todos estos problemas restan valor al 
texto, no deja de ser un logro el haber reunido este material y haberlo publicado en forma atractiva. El tema invita a continuar estudiando.

Clara Bargellini

\begin{abstract}
Baticle, Jeaninne, Bottineau, Yves, Btown, Jonathan y Pérez Sánchez, Alfonso E., Zutbarán, ensayos de... Catálogo. Patís, Editions de la Réunion des Musées Na. tionaux, 1988.
\end{abstract}

Reza un refrán popular: "A cada santo le llega su fiesta". Mutatis mutandis lo mismo puede decirse de los países cuando, por diversas razones, se ponen de moda. Eso es lo que ocurre actualmente con España que, de unos quince años a la fecha "está en el candelero"; como si quisiera recuperar los años que se mantuvo al margen de la escena mundial. $Y$ es muy significativo que en esta proyección de España hacia el exterior, América Latina ocupe un lugar importante. Nunca es tarde para enmendar errores pues, desde fuera, es un hecho que España había mantenido un gran distanciamiento con sus antiguas posesiones ultramarinas. Debemos felicitarnos, de uno y otro lado del océano, por este benéfico reencuentro. Esta apertura incluye, naturalmente, una política cultural en que encuentran cabida diversas actividades artísticas como es la organización de exposiciones internacionales de arte español, dentro y fuera de la península; entre las cuales vale la pena recordar las consagradas a El Greco -que tuvo lugar en Madrid, Washington, Toledo, Ohio, y Dallas - en 1982 y a Murillo, esta última presentada en Madrid, también en 1982 y en Londres al año siguiente. Digna también de mencionar es la exposición que años antes (1979-1980) se presentó en París, Burdeos y Madrid, bajo el sugestivo nombre de L'Art européen a la Cour d'Espagne au $X V I I I^{c}$ siècle. Y nos estamos refiriendo al arte de los siglos XVI a XVII; pero es indudable que no han sido pocas las muestras que se han visto de arte contemporáneo español. Sobre todo las que tuvieron lugar el año pasado (1987) en París; de la cual, la de Zurbarán, según dio cuenta la prensa internacional, resultó verdaderamente apoteótica.

Es práctica frecuente que toda exposición vaya acompañada de un catálogo. Sin embargo, pensamos que en los últimos veinte años esta práctica ha tomado un sesgo particular, en el sentido de ir más allá de lo que, en su acepción más llana significa la palabra catálogo. El resultado ha sido la elaboración de auténticos estudios sobre el tema de la exposición; al menos eso es lo que ha ocurrido en los distintos casos que hemos mencionado. Pero, estamos convencidos, que otro tanto puede decirse de las exposiciones consagradas del arte francés o el italiano, por sólo citar los casos extremos.

Tal empresa —es decir la organización de exposiciones sobre arte españolha sido posible gracias a los intercambios culturales sostenidos entre el gobierno hispano y los de otros países, verbi gracia los Estados Unidos de Norteamérica, Francia e Inglaterra, entre los más importantes. Decimos esto porque, tal como se encarga de remarcarlo Jeaninne Baticle -comisario general de la exposición Zurbarán-- fue gracias al esfuerzo del Museo Metro- 
politano de Nueva York, y a los empeños de la dirección general de los Museos Nacionales de Francia, además de la inapreciable ayuda de distintas instituciones españolas y no menor númerd de particulares y museos de varias partes del mundo, que pudo llevarse a cabo la muestra consagrada al maestro de Fuente de Cantos. Por eso son muy adecuadas las palabras de la misma J. Baticle cuando escribe: "Hay momentos de gracia en la vida cultural de las naciones, en que todas las condiciones se reúnen armoniosamente para celebrar el genio de un maestro al que los azares de la historia no habían permitido rendir justicia. Francisco de Zurbarán es uno de ellos. Considerado en su país, España, como uno de los más grandes pintores del siglo de oro, su reputación no siguió la misma trayectoria internacional pues nunca ha sido objeto de una gran retrospectiva fuera de las fronteras de la peninsula ibérica". Y añade, de manera bastante emotiva al final de los agradecimientos que preceden al libro, "quisiera que estas últimas líneas sean un vibrante homenaje a mis queridos amigos españoles, a quien debo un mejor conocimiento de los grandes maestros del Siglo de Oro. Gracias a su ayuda científica, y a los generosos préstamos de los museos españoles, nos ha sido posible reconstruir la historia de los conjuntos monásticos pintados por Zurbarán..." (p. 19). ¡Qué humildad y grandeza a la vez de esta historiadora del arte! Sí, una empresa de tal envergadura sólo es posible llevarła a cabo con amplios recursos económicos. . . pero sobre todo con sabiduría, seriedad y respeto académico entre colegas; lo que por desgracia no ocurre en otras latitudes.

Desde un principio Olivier Chevrillon - por el lado de Francia- y Philippe de Montebello - de parte de Estados Unidos- previenen al lector, en un ameno Avant-propos de lo que va a leer: "el arte de Zurbarán es, a la vez, el producto y la perfecta expresión de su época y del lugar donde vivió" (p. 14). Quien tome, pues, el catálogo entre sus manos, deberá tener la paciencia suficiente para hojear y ojear sus trescientas sesenta y seis páginas entreveradas con setenta y tres espléndidas láminas en color y no menos de cien en blanco y negro; estas últimas de distinto tamaño. ¿Puede pedirse un repertorio fotográfico más amplio para formarse una idea del arte de Zurbarán y del de sus contemporáneos? En medios como el nuestro, disfrutar un libro como éste resulta un auténtico regocijo.

Procedamos entonces a analizar el catálogo en cuestión: por su aspecto, el libro no se aparta de los modelos tradicionales a que nos tienen acostumbrados los Museos Nacionales de Francia; en la cubierta aparece, ocupando casi toda la plana, una bellísima reproducción en color de la Santa Margarita de la Galería Nacional de Londres. A la izquierda, en líneas rojas y dispuesto de manera vertical, se lee el nombre del maestro. El libro está constituido por el catálogo en sí —realizado bajo la dirección de J. Baticle- y cuatro ensayos sobre la vida y la obra de Zurbarán, escritos por J. Baticle, Yves Bottineau, Alfonso E. Pérez Sánchez y Jonathan Brown; todos ellos eminentes conocedores del arte español y en particular de la pintura. Habría que añadir que, de una u otra manera, los cuatro ya se habian aproximado a la obra zurbaranesca. De modo que en esta ocasión eran los más autorizados para hablar del maestro de Fuente de Cantos.

En sentido estricto deberíamos, en primer término, comentar los ensayos de estos autores. Sin embargo, solicitamos la benevolencia de nuestros lec- 
tores pues hemos preefrido hablar primero del catálogo para, después, ocuparnos de los estudios citados.

Las obras expuestas son setenta y tres, las cuales registra concienzudamente el catálogo. En conjunto proporcionan al visitante -0 al lector, en este casouna visión general, que casi puede considerarse totalizadora, de la producción zurbaranesca. Salvo los conjuntos que no son fácilmente transportables -como el del santuario de Guadalupe, en Extremadura- se procuró dar una idea precisa tanto de los cuadros, concebidos y realizados como obras independientes, como de aquellos que formaron parte de conjuntos, fueran retablos o series de lienzos, y que desafortunadamente se dispersaron, verbi gracia las pinturas con pasajes de la vida de san Pedro Nolasco, pertenecientes al convento de la Merced Calzada de Sevilla, o las pinturas del retablo mayor de la Cartuja de Nuestra Señora de la Defensión (números 26 a 30 del catálogo).

Cada obra ameritó una fỉcha o cédula especial que incluye, además de los datos de carácter técnico (material, medidas, fecha y firma y lugar donde se encuentra la obra), el sitio de procedencia de la obra, las fuentes manuscritas donde aparece citada, su historia, la bibliografía, y el estudio iconográfico y estilístico de la obra en sí. Cuando se trata de obras que pertenecieron a un conjunto, va precedido de una nota histórica acerca del lugar, acompañado de un plano del conjunto, además de uno o varios esquemas, para formarse una idea precisa de donde se encontraba la obra, por ejemplo las pinturas del Colegio de San Buenaventura de Sevilla.

Cada uno de los puntos registrados en la cédula puede decirse que pretende ser exhaustivo. En la medida de lo posible también se dan las fuentes literarias que pudo conocer el pintor $y$, en muchas ocasiones se incluyen grabados en los que Zurbarán se inspiró directamente para sus composiciones. Citaremos dos ejemplos al respecto: los cuadros que representan a Santa Apolonia (Museo de Louvre) y a Santa Lucia (Museo de Chartres); ambos provenientes, tal vez, de la iglesia del convento de la Merced Descalza en Sevilla.

En cuanto al apartado en el que se estudia la obra, los autores del catálogo tuvieron cuidado de señalar, entre otros aspectos, el que se refiere a precisar cuándo se trata de obras hechas por el maestro, para distinguirlas de aquellas en que es muy evidente la mano de sus ayudantes. Sería el caso de las pinturas de la iglesia parroquial de Marchena; conjunto del cual solamente la Inmaculada Concepción (número 25 del catálogo) sería de mano del maestro.

En suma, el lector puede consultar directamente las fichas, eludiendo los estudios consagrados al maestro. En cada una de ellas encuentra la información suficiente sobre la obra que le interese y las relaciones que guarda con la totalidad de la producción zurbaranesca e incluso de otros pintores de la época.

Por lo que se refiere a los ensayos diremos que el primero de ellos, con el sugestivo título de "Mecenazgo y Piedad", se debe a Jonathan Brown, quien se ha ocupado de la pintura española del Siglo de Oro en varias oca. siones. El título da a entender que analiza los diversos encargos que recibió el pintor por parte de varias instancias: comunidades religiosas, particulares, la Nobleza e incluso la Corte. Respecto a esta última clientela, dice Brown, "un encargo en la Corte representaba el sueño más caro para un pintor español del siglo XVII. Probablemente nunca sabremos si Zurbarán 
participó de este sueño y regresó a Sevilla únicamente porque no se le invitó a permanecer en Madrid; o si le repugnaba renunciar al casi monopolio de encargos artísticos en su ciudad de adopción" (p. 35-36).

El autor hace notar también que en la producción destinada a lo que podríamos considerar como un mercado periférico, o sea lugares lejanos a Sevilla y, sobre todo, el Nuevo Mundo, no se advierte mayor calidad y sí en cambio es evidente la participación de su taller. Respecto a la obra enviada a América, escribe Brown, "los temas son simples y la calidad de ejecución es a menudo mediocre. Su taller se especializó igualmente en la ejecución de conjuntos de cuadros consagrados a un solo tema, lo que permitía al cliente hacer una sola compra, decorar una iglesia o casas particulares. Así son las series enteras (generalmente una docena a veces veinte) de fundadores de órdenes religiosas, de doce emperadores romanos, y de doce hijos de Jacob, considerados los ancestros lejanos de los nativos de América. Zurbarán exportó igualmente a América series de Cristos, Apóstoles y escenas de la vidạ de la Virgen. No hace falta remarcar que el conjunto de esas pinturas fue ejecutado por su taller siguiendo la dirección del maestro. Su efecto no fue menos considerable sobre el Nuevo Mundo, donde Zurbarán se convirtió en el artista con más influencia en esa época.

Ahora bien, en toda la producción del maestro se advierte la influencia de la Iglesia - sobre todo en la iconografía-- tratando de hacer prevalecer los principios del Concilio de Trento. Sin embargo, eso no quiere decir que los artistas y los clientes no tomaran en cuenta la calidad; aunque también es un hecho que "representaciones mediocres pueden inspirar pensamientos elevados, pero la belleza resulta más adecuada para estimular el alma".

Al continuar su análisis el autor dice que hacia 1640 se produce un cambio de gusto y también en la iconografía. Antes se trabajaba más dentro del espiritu de la Contrarreforma y a partir de ese momento, artistas jóvenes como Murillo y Herrera El Joven implantan un nuevo sipo de imágenes. Tal vez por eso Zurbarán fue a Madrid donde la pintura estaba más avanzada que en Sevilla. Es por eso que el juicio con que termina su ensayo el autor, nos parece bastante lapidario e injusto, y contrasta ciertamente con el de J. Baticle, según se verá más adelante. Dice Brown: "Una nueva apreciación de la obra de Zurbarán muestra que, en un momento dado, su estilo se adaptó perfectamente a la clientela y que le confirió una expresión elevada, marcada de dignidad, a la forma heroica de la vida y de la devoción cristianas. Aún cuando el nombre de Zurbarán no evoca el de un pintor erudito a la manera de Pacheco, el hecho es que dio lo mejor de si mismo al intepretar la historia de los dogmas cristianos. Pero la sintesis que llevó a cabo, entre ideas y espiritualidad, cuando la fé católica se orientó cada vez más hacia una expre. sión sentimental, resultó de menos gusto para su clientela. Al tratar de adaptarse a las nuevas condiciones, no logró este cambio con suficiencia para establecer una diferencia. Así en los últimos años de su vida descendió a la regi6n crepuscular en la que permanecen los artistas pasados de moda" (p.44).

Yves Bottineau, a quien se deben enjundiosos estudios sobre arte español, dedica su ensayo, titulado $A$ propos de la fortune critique de Zurbarán: réflexions et interrogations, al análisis de la fortuna crítica del pintor añadiendo 
no pocas y novedosas reflexiones, así como el hecho de plantear nuevas interrogantes. Bottineau no pretende hacer un análisis exhaustivo del tema; sin embargo, con grandes trazos muestra la fortuna de Zurbarán en Sevilla, luego su "fracaso" en la Corte de Felipe IV y hace notar su ausencia en otras colecciones reales; para alcanzar notoriedad en España en el siglo siguiente. Cosa que no ocurrió ni en Inglaterra ni en Francia.

La gran actividad de los franceses (políticos, viajeros y artistas) que "descubrieron" España a lo largo del siglo XIX, suficientemente mencionados por Bottineau, no ayudaron a mejorar la fortuna crítica de Zurbarán pues personajes como Gautier, primero, y mucho más tarde Elie Faure, muestran que a Zurbarán se le vio "encerrado en una rigidez trágica y sombría".

La renovación de Zurbarán es obra de nuestro siglo, a partir de la muestra de su obra llevada a cabo en Madrid, en 1905; y se considera que la serie de grandes monografías sobre él comenzó con la de Cascales y Muñoz (1911). Enseguida pueden mencionarse, al menos, las de H. Kehrer (1918) y Martín Soria (1955).

Números especiales de revistas eruditas aportaron novedades en ocasión del tercer centenario de la desaparición del maestro (1964). El conocimien. to de Zurbarán "se precisaba; parecía típicamente español, historiadores y críticos de arte lo pasaban de un segundo plano al rango de unos de los primeros entre los pintores de su país" (p.53). Casi como homenaje Bottineau cita a los zurbaranistas más apasionados - Caturla y Guinard- quienes dedicaron gran parte de su vida al estudio del maestro. Otros investigadores más jóvenes, Brown y Pérez Sánchez, por ejemplo, han contribuido notablemente a un mejor y más completo conocimiento de Zurbarán.

"El ambiente artístico sevillano del primer tercio del siglo XVII" se titula el ensayo de Alfonso E. Pérez Sánchez -mactual director del Museo del Pradoquien con su habitual capacidad de síntesis resume el panorama artístico de la ciudad andaluza, desde fines del siglo XVI hasta el momento de mayor gloria alcanzado por Zurbarán. Época en que dicha ciudad conoció la etapa más gloriosa de su historia, en los tiempos modernos; debido, entre otras causas, al papel comercial que desempeñó en relación con los territorios de ultramar. En ese tiempo, "las iglesias y los palacios de la nobleza hervian de obras de arte, la ciudad y los talleres conocían una animación extraordinaria"s.

Pérez Sánchez hace un espléndido resumen de los principales aspectos que conforman ei panorama artístico sevillano: iconografía (influencia de la Iglesia y de los escritores religiosos sobre la creación artística), influencias artísticas (italianas, con Caravagio, en primer término, flamencas y otras de carácter local), géneros artísticos (surgimiento de la naturaleza muerta y resurgimiento del retrato), personalidades (Pacheco, Roelas, Ribera, Velázquez y otros pintores menores) y la organización del trabajo en gremios regidos por Ordenanzas.

Tras un enjundioso análisis Pérez Sánchez concluye: "el conjunto de la tradición sevillana constituye el soporte de la personalidad de Zurbarán. El joven pintor aprovechó la lección de todos esos maestros, tanto sus predecesores como sus contemporáneos. Otros factores intervinieron igualmente en la evolución de su estilo: el espíritu piadoso de su clientela está resaltado 
por la emoción y el impacto de lo cotidiano, de lo cual da testimonio la enseñanza devota de la composición del lugar jesuita, que visualiza con fuerza y sensibilidad el objeto de la meditación. Por otra parte, la circulación de estampas, flamencas e italianas, utilizadas sin reserva en todos los talleres de pintura como recurso fácil; ahí, donde la invención comete errores pero también luego que la clientela lo impone. Estos patrones precisan a menudo la iconografía de las figuras de devoción contemporánea. Todo esto permite resaltar lo que Zurbarán debe a su tiempo y a su medio, dibujando el horizonte cultural sobre el que destaca la personalidad del pintor... Gracias a este balance, con sus límites evidentes, Zurbarán llega a una prodigiosa y conmovedora síntesis de grandeza y sutileza, de simplicidad y misterio, que da la clave de su expresión, altamente personal" (p. 70).

El párrafo anterior, nos parece, da idea cabal del ensayo de Pérez Sánchez, gracias al cual percibimos cómo puede entenderse la importancia del maestro de Fuentes de Cantos.

En él último de los ensayos Zurbarán: aperçu de sa vie et de son oeuvre, J. Baticle presenta un bosquejo de la vida y la obra del maestro, apoyada en las investigaciones llevadas a cabo por los más eminentes zurbaranistas españoles y extranjeros; entre los que no puede dejar de citarse a María Luisa Caturla, Diego Angulo, Cesar Peman y Paul Guinard; gracias a ellos se conoce ampliamente mucho de la vida y de la obra de Zurbarán. Sin embargo, son muy agudas las observaciones personales de J. Baticle; por ejemplo cuando señala que Pacheco, en su obra de tratadista, ignoró a Zurbarán. Ese silencio "¿no será un indicio de su reprobación hacia el insumiso pintor que pronto ejercería su oficio en Sevilla sin someterse a la práctica común de presentar el examen correspondiente?" O bien la importancia que tuvo, en la evolución de su estilo, el viaje que hizo a Madrid. Ahí conoció a pintores italianos; así, "a partir de 1635-36 se advierte un cambio en la factura de sus obras, aunque permanezca atado a las formas estáticas y monumentales, a las composiciones sobrias y simplemente armonizadas de la década anterior" (p. 77).

Más adelante, J. Baticle se manifiesta en contra de algunas observaciones hechas por otros autores en cuanto a la evolución del arte de Zurbarán. "En esta década [los años cuarenta del siglo XVII] el pintor español se encuentra en perfecta simbiosis con la evolución estética de su época y, también, se decoran menos iglesias en Sevilla; es simplemente por eso que los encargos resultan menos numerosos; lo cual no quiere decir que su arte haya decrecido" (p. 80). Y en relación a esta misma época Baticle señala como "el colonial ocupa un lugar importante en la actividad de Zurbarán... tal vez en razón de la baja de encargos en Andalucía. . . Esto probaría que la clientela escaseaba en Sevilla" (p. 81).

Al mediar el siglo XVII el estilo del maestro siguió evolucionando; así lo prueba el cuadro de La Anunciación (hoy en día en el Museo de Arte de Filadelfia) de Peñaranda, que "es una obra importante pues prueba que para esa fecha Zurbarán se ha convertido a la hechura en esfumato y que busca disminuir la rigidez de las formas a las que estaba acostumbrado antes" (p. 83). Características que también se aprecian en el cuadro de Cristo con la cruz a cuestas (catedral de Orleans). 
A propósito del último viaje del maestro a Madrid, la autora comenta que las obras que pintó "desdeñadas por los primeros críticos del pintor, y que ímporta revalorizar hoy, prueban que la capacidad creativa del artista no se detuvo con los años, a pesar de los trastornos políticos, sociales y estéticos, y que él sabe orientar hacia una forma de arte nuevo y audaz que no debe nada al ambiente barroco" (p. 85).

Aunque extenso, queremos citar el párrafo escrito por J. Baticle al fínal de su ensayo pues muestra claramente la grandeza del maestro de Fuente de Cantos. Cuando se encontraba en Madrid, donde murió en 1664 , no vivía su mejor momento, "a las desgracias de su vida privada se sumaron la muerte de Velázquez en 1660 , el amigo fiel y todopoderoso, la decadencia entre 1660 y 1665 del reino de Felipe IV, enfermo y arruinado, y la evolución cultural que se producía en España en el último tercio del siglo XVII, hacia una teatralidad de la religión y de su imagen, que no iba de acuerdo con la calmada y pujante reserva de Zurbarán. Pero se cometería un gran error al creer que esta conjunción hizo decrecer el poder creativo del maestro, pues en esta áltima etapa el papel del taller, otrora un tanto excesivo, es casi nulo; es el gran Zurbarán, él mismo, quien vierte sobre la tela sus poéticos sueños, valién" dose de una impecable maestría en el arte de pintar adquirida a lo largo de tantos años de encarnizado trabajo" (p. 87).

Quien haya tenido la paciencia de leer lo que hasta aquí hemos escrito, advertirá por qué lo hemos hecho. Una revisión superficial de cualquier manual de arte novohispano muestra, enseguida, cuánto debe la pintura barroca del virreinato a sus fuentes peninsulares. Pero, sin duda, es la producción Zurbanesca la que influyó de modo más sensible. Era normal, la fama del maestro atravesó el Atlántico y no dudamos en pensar que más de un indiano nuevo rico deseara poseer un cuadro salido del obrador del extremeño. Así lo prueban por ejemplo las investigaciones de María Luisa Caturla, concentradas en su artículo titulado "Zurbarán exporta a Buenos Aires".

Por lo que se refiere a la pintura novohispana, fue evidente la impronta zurbaranesca a partir de la llegada de Sebastián López de Arteaga, de quien se dice fue alumno del maestro. Después de ese momento los pintores novohispanos sucumbieron a los encantos "claroscuristas" o "tenebristas" que no abandonarán sino casi un siglo después. No sabemos por ahora cuánto haya exportado Zurbarán a la Nueva España; que se conservan obras de su mano lo prueban dos cuadros incluidos en este catálogo: Los discípulos de Emaús (Museo de San Carlos de México) y viaje de San Pedro Nolasco hacia Barcelona (Museo Franz Mayer, ciudad de México); aunque únicamente el primero, al parecer, está en México desde la época colonial. El segundo es una adquisición más rèciente.

En cambio abundan los cuadros anónimos de filiación zurbaranesca. Historiadores como Diego Angulo, Antonio Bonet Correa y, sobre todo, Xavier Moyssén han llamado la atención sobre varios de esos cuadros. Sin embargo, al visitar decenas de iglesias -en el campo y en las ciudades- es frecuente encontrar lienzos "zurbaranescos". ¿Cuál fue exactamente la fuente gráfica en que bebieron los pintores novohispanos? ¿Tuvieron a la vista lienzos del maestro, de su taller o fueron simplemente grabados los que manejaron? Lo deleznable de unos y otros tal vez nunca permita saber, bien a bien, cuál fue 
la vía de su conocimiento. Lo que quedaría por hacer, en todo caso, sería un corpus de esas obras dispersas en iglesias, bodegas de museos y en colecciones particulares, para perfilar un poco mejor la influencia de Francisco de Zurbarán en la pintura del otrora virreinato de la Nueva España.

Tarea que espera a uno o varios jóvenes investigadores, provistos de una sólida formación, pero también con sensibilidad e imaginación para penetrar en ese mundo fascinante y enigmático que es el de la pintura. Si entre alguno de los lectores de esta ya larga reseña saliera la vócación a la que aludimos, sería el mayor y más justo homenaje que pudiera recibir, de este lado del Atlántico, el ya ausente maestro Diego Angulo, por quien existe en gran medida la pintura novohispana.

\section{José Guadalupe Victoria}

Annie Jacques, La Carrière de l'architecte au $X I X^{\circ}$ siècle, Les Dossiers du Musée D'Orsay 3, Paris, Editions Mussées Nationaux, 1986.

El nuevo museo parisino, el Musée D’Orsay, alberga en su amplio recinto un sinnúmero de expresiones artísticas, predominantemente francesas, del siglo pasado. Asimismo se ha dado a la tarea de organizar exposiciones temporales sobre diversos temas relativos al arte decimonónico; éstas vienen acompañadas de un catálogo o expediente, "Dossier", que permite conservar y trans" mitir lo más relevante de dichas muestras. En el caso que nos ocupa, relativo a la carrera del arquitecto en el siglo XIX, la exposición se llevó a cabo de diciembre de 1986 a marzo de 1987, y su expediente fue el tercero de los establecidos por este museo.

E1 catálogo, redactado y organizado por Annie lacques, Conservadora de la Biblioteca y de las Colecciones de la Escuela Nacional Superior de Bellas Artes, posee una serie de cualidades que ameritan analizarse. En efecto, la autora presenta un acucioso análisis de los estudios y la profesión del arqui. tecto francés en el siglo pasado, basándose en el profuso material gráfico mostrado en la exhibición, y que se reproduce en parte para ilustrar adecuada. mente el ensayo. Su interés reside en el aporte que hace con respecto al tema de Beaux Arts en la adecuación del arquitecto decimonónico, como asunto central de la publicación, y no sólo un punto de vista o apartado en una presentación más amplia.

Es innegable que en el propio siglo XIX y los principios del $X X$, se dieron buen número de escritos que, a manera de memorias, trataron principalmente sobre la escolaridad en la renombrada escuela parisina; en México, el arquitecto Manuel Francisco Alvarez en La enseñanza de la arquitectura en el extranjero y en México, publicado por la antigua imprenta de Murguía, en 1914, se refiere tangencialmente a este tema. Sin embargo, en este trabajo Annie Jacques se preocupa por deslindarlo con base en los diversos escritos de índole autobiográfico o simplemente estadística de la época, y apoyándose en los documentos gráficos ofrece una visión esclarecedora. Así, algunos de los mitos 
sobre la vida de los arquitectos decimonónicos se rompen, y se obtiene una información confiable y real.

Asimismo, la autora aprovecha la ocasión para trazar en los diversos apartados del libro una visión totalizadora de esta profesión en el siglo pasado, desde la enseñanza, la práctica, el reconocimiento, los enfrentamientos con la ingeniería y sus principales éxitos. Como el título de la publicación lo indica, una porción importante está dedicada a la famosa Escuela de Bellas Artes de París, líder y ejemplo en su momento, y que explica los sistemas, los planes de estudio, los cambios sucesivos y en especial el codiciado "Prix de Rome", máxima presea y presagio de logros futuros. Así se ofrecen, hábilmente integrados, datos históricos con anécdotas personales para conformar un marco fidedigno de la profesión edilicia, premonitorio de situaciones aún actuales.

Para el caso específico de los arquitectos y la arquitectura mexicana del siglo XIX, este texto esclarece muchos puntos, si tenemos en cuenta la asistencia de un buen número de mexicanos a esta escuela, así como por la idea que se tuvo de ella como el modelo a seguir. Esto, aunado a la presencia de profesionistas franceses tanto en la docencia como en la práctica en nuestro país, afina aún más la imagen de las repercusiones en el ámbito nacional. En este sentido se aprecia el que los números 67,68 y 69 del catálogo estuviesen dedicados a Emile Bernard y su "Palais pour l'exposition de Beaux Arts". Asimismo se comprende que la obtención del diploma final no turviese demasiada importancia, por lo que, establecido en 1867, para 1876 contaba tan sólo con nueve titulados; esto explica que estudiantes de la importancia de Antonio Rivas Mercado no se preocupasen por correr el trámite, el que realizó en su propio país en 1879 por obvias razones legales.

En resumen, este libro, tanto en el texto como en las imágenes, entriquece el conocimiento de la profesión del arquitecto en el siglo pasado, cuya comprensión es básica para explicar las derivaciones en la época contemporánea. Por ello, quien se interese en el acontecer moderno de la arquitectura encontrará en este "Dossier" respuesta a muchas interrogantes que darán mayor profundidad a sus conocimientos.

\section{Louise Noelle}

Huxtable, Ada Louise, Arcbitecture any. one?, Cautionary tales of the building ant, Randon House, New York, 1986.

Ada Louise Huxtable es una de las periodistas de mayor prestigio dentro del campo de la crítica arquitectónica, con casi dos décadas en su haber de colaboraciones en el New York Times. Esta es una de las formas de crítica que más popularidad y alcance han tenido, tanto por su inserción en los medios masivos de comunicación como por sus cualidades de evaluación y comentarios para un público no especializado. En este caso la calidad de los artículos, su constancia y la influencia que han ejercido en los usuarios de la arquitectura, han propiciado el reconocimiento de que disfruta esta escritora, pio- 
nera en este campo, y con justicia ha recibido, al lado de Cristian NorberSchuts, el premio Jean Tschumi en el XVI Congreso de la Unión Internacional de Arquitectos.

Se trata, en efecto, de una recopilación de artículos publicados recientemente, 1977-81, en el diario neoyorquino, lo que permite tener al alcance $y$ en un solo sitio, parte de aquellos textos que sólo un número de lectores del mencionado diario habían leído y muy pocos conservado; situación especialmente favorable para quienes, en el tiempo y en el espacio, estuvieron lejos de dicha publicación. En este sentido otro libro de la autora, aparecido también en 1986, es de tenerse en cuenta, Goodbye history hello hamburger. An Antology of architectural delights and disasters, The preservation press, Washington, 1986; aunque es preciso apuntar que se trata de la reedición de dos trabajos anteriores $W$ ill they ever finish Bruckner buolevard? y Kiked a building lately?, en los que reunió artículos que aparecieron entre 1963 y 1976.

El libro Architecture Anyone fue preparado por la señora Huxtable cuando abandonó su puesto de crítica del New York Times, al recibir el nombramiento de MacArthur Fellow, con una beca para poder trabajar independientemente en los temas de su elección y predilección; es comprensible esta actitud si se tienen en cuenta las presiones que conllevan las colaboraciones en un periódico, diarias y semanales, tanto por sus plazos irrevocables como por lo comprometido de algunos temas. Los ensayos fueron ampliados y puestos al día para esta ocasión, guardando intactos los juicios y opiniones. Se encuentran agrupados bajo los siguientes rubros: Architecture anyone?, The past as future, Modernism revisited, Beyond modernism, the near and distant past, Cities, Buildings, Places and pleasures, Side trips, Design for living y The joy of architecture, con una introducción y un índice de gran utilidad al final.

Por este medio la autora logra asociar un amplio número de textos, más de sesenta, sobre muy diversos temas, pero todos de actual y continuo interés. Estos tienen como centro de acción la ciudad de Nueva York, por razones obvias; sin embargo, no se circunscriben a esta metrópoli, abarcan un espectro mundial. Por una parte se ocupa de diversos sitios y edificios en Estados Unidos, así como de Europa y del resto del mundo y por otra, analiza la obra de arquitectos contemporáneos, tanto americanos como extranjeros, y otros del siglo pasado. De esta manera y con el pretexto de la reseña de alguna exposición, se avoca, con gran conocimiento de causa, a ilustramos sobre personajes como Eugène Viollet-le-Duc, Ailvar Aalto o Michael Graves.

Resulta importante anotar la mariera y el sentido con que están realizados los artículos, puesto que casi todos siguen el mismo esquema. Ada Louise Huxtable utiliza una exposición o una obra arquitectónica como el tema central de cada apartado, y sobre este tema amplía nuestros conocimientos; en algunos casos su visión sobre hombres y obras es positiva, rescatándolos de malentendidos o maledicencias; en otros casos, casi siempre relacionados con el urbanismo, realiza críticas demoledoras sobre la grave y caótica situación actual de las grandes ciudades. Siempre y con valor, toma partido ya sea para defender y rescatar o para apuntar los errores y exigir soluciones, exponiendo con claridad y lógica objetiva los elementos de sus argumentos. Se trata de textos cortos que siguen una clara secuencia explicativa y que 
guardan siempre para el párrafo final una frase aguda que redondea y cierra la exposición. En algunas ocasiones presenta dos o más artículos escritos en diferente momento sobre el mismo asunto, en los que ocasionalmente se agregan aclaratorias. Si bien actualmente los interesados en estos textos están relacionados más o menos directamente con la arquitectura, en su momento los escritos cumplieron con creces su función con el público en general, gracias al claro estilo descriptivo de la autora y al cuidado que puso para que fuesen accesibles para los lectores comunes; su vocabulario es exacto y su acercamiento instructivo, sin miedo a ser demasiado explícita en el contexto histórico, logrando con éxito sus fines.

Así, aparece ante nuestros ojos un nuevo Le Corbusier, redimido después de muchos años de incomprensión, a través de una visita y una revisión acuciosa de la obra de los "Quartiers Modernes", en Pessac; este viaje sirve de pretexto para presentarnos al gran arquitecto suizo, y además de plantear una nueva visión sobre su obra, aprovecha la ocasión para introducir un adecuado contexto histórico. En otro caso, el de la adición al Museo de Arte del Oberlin College por la firma Venturi, Rauch y Scott Brown, su acercamiento sin prejuicios y la profundidad de su análisis, logra una evaluación positiva del edificio; de esta manera el tema del postmodernismo entra en escena, siendo tratado racionalmente y recibiendo, cuando asi lo amerita, la aprobación de la señora Huxtable. Una gran lección es la que recibimos al ver cómo cada obra, cada dibujo y cada arquitecto le merecen una atención cuidadosa, evitando juicios temerarios y posiciones radicales, con lo que el resultado es siempre edificante.

De la misma manera rescata a un urbanista olvidado, Clarence Stein, apuntando sus aciertos visionarios o nos muestra la evolución y la trayectoria de James Stirling, a través del museo Fogg de Harvard. Asimismo nos informa sobre el quehacer de un arquitecto ruso, Ivan Leonidov, casi desconocido para nosotros, al explicar su obra dentro de su contexto sociocultural. Revisa así edificios que en su momento levantaron comentarios enconados, extrayendo acuciosamente sus logros y marcando instructivamente sus errores, como en el Museo Pompidou de Piano y Rogers, o la adición al Hospital del Bronx de Richard Meier. Muchos son los temias tocados y es imposible aquí referirnos a todos; basta añadir que cubren una amplia gama de la arquitectura moderna. Así, estos escritos, esclarecedores en su momento, adquieren actualmente estatura dentro de la historia.

La propia autora comprende y aprecia el valor de sus textos puesto que la conjunción de unos principios sólidos y del texto impreso, representa para los críticos una de las armas más poderosas de esta época. Su trayectoria ha sido aleccionadora, $y$ sus enseñanzas valiosas, dejando un buen número de logros en sus defensas y un amplio grupo de seguidores. Concluyamos con sus propias palabras: "The critic's view of the art of architecture must embrace the policy and the culture that are inseparable from it; the critic is the link between people and the buildings that made the public realm".

Louise Noelle 
Chris Abel, Transformations. Richard Eng. land, 25 years of arcbizecture, prólogo. J. M. Richards, Malta, Mid-Med Bank Limited, 1987.

Richard England es un arquitecto maltés cuyo renombre ha trascendido las fronteras de su pequeña isla nativa. En pocos años logró un reconocimiento local, lo que le valió para obtener gran número de comisiones, por lo que con veinticinco años de práctica profesional puede ya afirmarse en el ámbito de la arquitectura internacional. Su figura se intensifica cuando, junto a estos logros, surge la imagen de un espíritu renacentista que cultiva con éxito otras disciplinas como el diseño gráfico, la fotografía, el dibujo, la poesía y el ensayo. Por ello, en el caso de este libro, el tema se convierte en el punto nodal, como lo advierte el afamado J. M. Richards en su prólogo.

Es obvio que se trata de una publicación conmemorativa, que celebra un cuarto de siglo de creación arquitectónica mostrando, como su título lo indica, las transformaciones que ha tenido el arquitecto, sobre todo en el campo esti. lístico. Chris Abel plantea cuidadosamente el entorno y el pasado de Malta, para explicar a continuación la inserción respetuosa de la primera parte de - la obra de England y los cambios ocurridos posteriormente en su expresión plástica. Así, queda claramente expuesto cómo la tradición cultural centenaria de esta joven nación arranca de los tiempos megalíticos de 3700 a. C., pasa por los establecimientos de las diversas culturas que dominaron el Mediterráneo, y culmina con la fortificación de los caballeros de Malta en el siglo XVI y la ocupación inglesa. Todo este pasado logra amalgamarse a través del uso exclusivo del único material constructivo local, una piedra caliza de tono ambarino, cuyo color, cualidades y cortes unificaban todas las edificaciones.

Ante este legado, el joven arquitecto que retornaba de Milán de un período de estudios con Gio Ponti, supo apreciar su riqueza e inició una práctica imbuida de los preceptos de lo que hoy se conoce como regionalismo. Así, de la misma manera que Luis Barragán y un grupo de arquitectos mexicanos, sin negar los conocimientos y los avances técnicos de nuestro siglo, se opusieron a la frialdad y el anonimato de los movimientos internacionales para acogerse a una tradición local impregnada de factores emocionales, Richard England plantea entonces lo que hoy día se conoce con el nombre de arquitectura regional. A su manera, él fue también uno de los pioneros del movimiento regionalista que actualmente ha cobrado importancia, como uno de los caminos a seguir fuera del movimiento moderno ya caduco, pero sin caer en los excesos del postmodernismo.

Posteriormente, Chris Abel plantea un cambio expresivo en la obra de este arquitecto, cambio que coincide tanto con una modificación en el pensa. miento del autor como con sus primeros proyectos para un pais netamente diferente como es Iraq. Toda una serie de imágenes plásticas contenidas a través del tiempo en aras de una arquitectura que había escogido como direc. triz el respeto al entorno, sobre todo en los múltiples edificios de servicio turístico, así como el impacto de la riqueza del arte islámico, se vuelcan en una obra de paisajes de carácter personal, "Un jardín para Myriam". Aquf $\mathrm{y}$ en sus siguientes proyectos aparece un gran número de elementos arquitectónicos y plásticos, que en cierto momento lo acercan al postmodernìsmo. 
Se trata, sin embargo, más de una arquitectura de la memoria personal de la tradición y del autor; obras que en lo funcional y económico, cumplen a perfección con los requerimientos de programa, y que en lo estético representan una catarsis.

De esta manera este libro, rigurosa y cuidadosamente diseñado por el propio England, presenta a continuación del texto una serie de imágenes que am. plían nuestros conocimientos. Un primer apartado se ocupa de los antecedentes, "Inheritance", que nos muestran diversos aspectos del pasado de Malta, seguido de otros que recogen sus dibujos conceptuales, lo que en la actualidad los estudiosos de la arquitectura consideran de importancia para el puntual análisis de una obra. La sección más importante está dedicada a la ilustración tanto de edificios como de proyectos, planteada en tres subdivisiones: Formas de antigüedad. El reto de la ampliación y Una cultura intemporal, las que documentan sus diversas tendencias. En este sentido, la visión que se obtiene de este arquitecto es amplia y esclarecedora; sin embargo, es preciso mencionar la ausencia de esta publicación de elementos ilustrativos como plantas y cortes, lo que es indispensable cuando se busca una compresión más profunda de la arquitectura. Esto se comprende por el carácter de amplia difusión que se pretendió dar al contenido de este libro al ser una publicación de aniversario, por lo que quien desee un estudio más especializado deberá referirse a la obra de Charles Knevitt, Connections, publicada en Londres por Lund Humphries en 1983.

Asimismo, quien busque comprender la obra de Richard England en toda su extenisón, deberá acercarse a otras publicaciones realizadas por él mismo, y que muestran diversas facetas de su prolífica creatividad en otros campos. Es preciso aquí mencionar Walls of Malta, 1973, White is White, 1973, Island, a poem for seeing, 1980, In search of silent spaces, 1983, libros publicados en Malta y que dan cuenta de sus cualidades de poeta, fotógrafo y escultor, así como de sus intereses personales; se amplía así la imagen del artista y se aclaran algunas interrogantes. Por ello, ante la fuerte personalidad de England, este libro, Transformations, se constituye en un vehículo adecuado para introducirnos en el mundo de la arquitectura contemporánea del Mediterráneo y de uno de sus principales exponentes.

\section{Louise Noelle}

Gedo, John E. Portraits of the Artist. Int. Peter Gay. The Guilford Press. New York, London, 1986.

Es bien sabido que Freud afirmó en múltiples ocasiones que el psicoanálisis rendía sus armas ante el problema que plantea el origen de las dotes creativas. Llegó a hacer una distinción implícita entre genialidad y talento, pero a pesar de que echó luces acerca del proceso creativo en no pocos de sus escritos, siempre se empeñó en afirmar que "debemos confesar que la esencia de la operación artística resulta inasequible mediante el psiconálisis". En otro trabajo mío: Las ideas estéticas de Freud (Editorial Grijalbo, 1986, col. Enlace), me he ocupado de aclarar que la posición de Fred al respecto fue 
singularmente modesta y que existe una contradicción entre lo que afirmó con tanta contundencia al respecto y las interpretaciones que dio acerca de los posibles orígenes de la creatividad. No es pues el momento de ahondar en esta problemática que ya quedó formulada en el libro citado y que me propongo desarrollar más a fondo en uñ futuro estudio. Mi interés por la aplicación del psicoanálisis a la teoría $\mathrm{y}$ a la crítica de arte ha mantenido vivo mi intento de conocer las más recientes aportaciones que han aparecido en relación a este tema, sobre todo si se abocan al estudio del proceso creativo. Entre ellas son mayormente numerosas las que vienen del campo del psicoanálisis que las escritas por historiadores o críticos de arte. El libro del Dr. John E. Gedo, analista supervisor del Chicago Institute for Psychoanalysis y frecuente interlocutor del departamento de investigación en el Institute of Art de Chicago, se encuentra prologado por un historiador: Peter Gay y lo importante del texto de este último es que abiertamente muestra su excepticismo ante varios de los puntos que John E. Gedo maneja, haciendo una severa crítica a aquellos seguidores de Freud que no se han atenido suficientemente a las precisas indicaciones que el introductor del psicoanálisis marcó acerca de su aplicación al producto artístico o a la biografía del artista. Gay también exalta sus puntos de acuerdo y las aportaciones que encuentra en el libro. Manteniéndose "fiel" a Freud, exalta a K. R. Eissler, uno de los primeros teóricos sobre la creatividad que escribió un estudio con enfoque psicoanalítico. Peter Gay afirma que John E. Gedo "ha aceptado e introducido modos complementarios para interpretar el material", lo cual le parece prudente y acertado. Sin embargo, considera que los estudios psicobiográficos -elucidadores como en ocasiones lo son- no tienen carácter defi. nitivo en el contexto de la investigación sobre los orígenes de la creatividad. Para apuntalar esta idea cita las conclusiones diferentes a las que tres autores llegaron en dos psicobiografías sobre Beethoven, la de Mayard Salomon: Beethoven y la de Editha y Richard Sterba: Beethoven and his Nephew.

El libro del Dr. Gedo es un conjunto de ensayos vinculados entre sí a través de un propósito permanente: el de utilizar las herramientas que proporcionan los métodos de la psicología profunda contemporánea, "en la illu" minación de un aspecto de la cultura: las viscitudes del proceso creativo". La obra intercala capítulos conformados mediante estudios históricos con comentarios clínicos, provenientes de la práctica privada, de tal manera que en realidad usa su propia casuística. Incuye también un capítulo dedicado a Carl Gustav Jung: "La creatividad como profecia" y otro a Sigmund Freud, "Sigmund Freud y la tradición socrática". El libro concluye con un ensayo a manera de epílogo en el que analiza algunas de las relaciones entre artista y público: "El artista en la era de la cultura masiva: un profeta en el desierto".

Ya el título general del libro presenta una problemática digna de ser tomada en cuenta. El lector debe percatarse de que no se titula Portraits of aritists, sino Portraits of the Artist. Desgraciadamente el autor no explica el significado de la idea básica que transmite a través de este enunciado. Tratándose de un psicoanalista que respeta a Freud, por supuesto que debe prestar honda atención al enunciado general que supuestamente debe condensar en pocas palabras una rica serie de temas diversificados, pero unidos, como he dicho, a través de un mismo propósito. El título parece significar que no existe la 
posibilidad de to portrait (retratar) la personalidad de un artista a través de un escrito, por penetrante que éste sea. Lo más que puede hacerse es proporcionar ciertas claves que ayudan a traducir la mecánica de determinados procesos que se encuentran en los estratos profundos del creador, o sea de "The Artist". Estas claves no son univocas y por ello la palabra portrait se escribe en plural: portraits.

En la parte referida a la casuística bajo el subtítulo de Clinical studies, Gedo informa que "Ha organizado sus conclusiones clínicas acerca de la creatividad bajo cuatro encabezados separados", pero seguramente el material fue sometido a una fuerte revisión editorial, con lo que hay más apartados que los previstos por Gedo. De este modo el libro obedece a la siguiente organización: Después del prólogo y la introducción (el estudio de Peter Gay), hay un capítulo dedicado a la revisión bibliográfica acerca de la creatividad. El segundo capítulo, como he dicho, conjunta observaciones sobre los casos clínicos observados. Es conveniente aclarar que Gedo ha analizado un número considerable de escritores, poetas, pintores, diseñadores, etc., pero al parecer se trata de talented pople, no precisamente de artistas consagrados. Con frecuencia habla de outstanding capacities, pero aunque jamás maneje nombres propios (lo cual sería violar el secreto profesional) el lector entiende que ningún genio ha desfilado por su consulta, aunque sí algunas gentes de rasgos genialoides. A partir del segundo capítulo comenta en primer término los disturbios más comunes que pueden frenar la creatividad en todos los campos, derivando su modelo conceptual de un trabajo anterior de su autoría realizado en colaboración con su colega, Dr. Goldberg. El capítulo cuarto está dedicado integramente a la problemática específica que presentan las mujeres con dotes creativas. Las mujeres, dice, "parecen obstuir sus propósitos y metas creativas con mayor frecuencia que sus contrapartes masculinas". Las causas son, por supuesto, psicosociológicas, históricas y familiares. En cambio los homosexuales masculinos retienen y desarrollan sus capacidades, "aunque sus problemas de personalidad puedan ser severos en otras áreas de la conducta". La relación entre homosexualismo y creatividad se examina en un inciso aparte $y$, finalmente, en el capítulo sexto, intenta el abordaje de la personalidad del genio. Aquí es donde aparece el material de mayor interés para el historiador, el investigador, el teórico o el crítico de arte; los temas motivo del análisis son en todos los casos personajes cuya fama ha trascendido el momento, gente "consagrada" que ya ha sido motivo de múltiples estudios. El lector vuelve a encontrarse ante Caravaggio, Van Gogh, Gaugin, Cezanne y Picasso, así como con Beethoven, Wagner y Nietzche y con la semblanza de un escritor que quizá se encuentre entre las partes más logradas del libro. Me refiero a Joseph Conrad. Pienso que en cuanto a aportación personal este comentario sólo se parangona con el ya mencionado epílogo acerca de la inserción del artista en la era de una cultura de masas. Vuelve aquí a utilizar material clínico y proporciona sagaces observaciones acerca de los "insidiosos cambios de valores" característicos de nuestra cultura, de la tendencia generalizada a la creación de ídolos, propiciada por la publicidad dirigida a un consumo masivo, del artista y su público y... de la moda. Posiblemente en este último punto se encuentren sus más perspicaces y finas observaciones. 
No es mi intención resumir el libro, que además es bastante largo, trescientas tres páginas casi tamaño carta con una selección muy pertinente de ilustraciones en blanco y negro. Pero sí me parece importante anotar cuales son, a mi parecer, sus méritos y sus limitaciones.

Gedo maneja una amplísima bibliografía y una no menos rica hemerografia. Su mayor acierto al respecto consiste en que no se ha limitado a los autores de enfoque psicoanalítico o psicológico, sino que incluye también y casi en igual número a los historiadores, filósofos y teóricos del arte. Para quien desee involucrarse a fondo en un nuevo estudio sobre la creatividad, este volumen resulta imprescindible, contiene prácticamente todos los títulos relevantes sobre la materia, hasta el año de 1985 y varios más que pueden ser útiles o reveladores (cosa que no me consta, porque no los conozco, además de que Gedo acostumbra a ser muy parco en las citas textuales). Maneja predominantemente autores norteamericanos e ingleses, pero tambiẻn enumera la mayor parte de las obras de Freud que tocan el tema, asi como textos de autores alemanes, franceses e italianos, aunque en menor número. Lo que escribe sobre Caravaggio, Beethoven, Wagner y Nietzsche tiene valor principalmente de recopilación y síntesis. En lo que dice sobre Picasso hay una mayor aportación personal, la que quizá se deba a que la mujer de John E. Gedo: Mary Mathews Gedo, es una destacada psicoanalista e historiadora que se ha especializado en Picasso, incluso es autora de un libro en el que examina a profundidad principalmente la última etapa de la traw yectoria picassiana. El libro se titula Picasso. Art as Autobiography y está publicado por la University of Chicago Press.

Quizá algunos lectores, especialmente aquellos que por razones diversas se encuentran familiarizados con cuestiones psiquiátricas (aunque no sean lectores médicos), puedan encontrar forzados algunos diagnósticos que Gedo propone a manera de paradigmas. Por ejemplo: En el capítulo titulado "Terribilitá: The Paraoid Monster as Creative Genius", realiza una revisión bastante auciosa de la vida y las obras de Caravaggio, pero luego concluye el inciso con "una alusión a la obra de un gran pintor, comparable en estatura a Caravaggio. Este pintor fue capaz de logros máximos a tiempo que hacía frente a una paranoica crónica". Se refiere a Paul Cezanne. Lo que dice sobre el pintor de Aix, a quien reconoce como pilar no sólo de su momento, sino del arte del siglo $\mathrm{XX}$, es en términos generales correcto $\mathrm{y}$ elucidador, pero la etiologia de la paranoia no llega a fundamentarse de manera suficiente. Yo podría afirmar que a pesar de los numerosos insights que contiene el libro, sumados al amplísimo bagaje informativo, muchos puntos quedan truncos porque a Gedo le faltó inmiscuir una disciplina fundamental para el análisis de las dotes creativas y de la triada creatividad-neurosis-psicopatía: me refiero, por supuesto, a la genética. Esto no quiere decir que sus estudios carezcan de valía, todo lo contrario. Constituyen aportaciones interesantes y bien documentadas, aunque incompletas, acerca de un tema que hasta la fecha no ha sido abordado más que por un número relativamente corto de investigadores. 
García Guerrero. Con un texto de Carlos Monsiváis: "Luis García Guerrero: Novedad del paisaje", México, Editorial PROMEXA, 1987.

De entrada, el libro cautiva, y no es una metáfora sino que no puede dejarse fácilmente una vez que se ha abierto, y se duda en repasar el siempre insólito texto de Carlos Monsiváis ó en hojear las láminas con reproducciones de la obra plástica de Luis García Guerrero.

Cuarenta años de labor ininterrumpida constituyen el motivo central de esta edición a cargo de Promociones Editoriales Mexicanas, con el apoyo de Multibanco Mercantil de México, encomiando el paso la feliz iniciativa del empleo de recursos privados en un trabajo editorial como el presente, que logra un alto nivel cualitativo en su realización técnica y formal.

Pero no solo la forma es cuidada con esmero en esta publicación, el texto es encomendado a un escritor que, por su bagaje cultural e informativo, aporta las más de las veces un enfoque agudo y novedoso de los temas que trata, en este caso, de la obra del pintor García Guerrero. En breves, pero contundentes líneas, se suceden imágenes, conceptos, cuestionamientos, aseveraciones $\mathrm{y}$ recursos literarios sorprendentes, desplegados en el tono ágil y provocador que Monsiváis emplea en sus escritos. Ágil, porque desfilan unos y otros con vertiginosa rapidez, a veces sin dar tregua para captar sus posibilidades, su ironía, su incisivo poder de observación; provocador, porque todo texto de Monsiváis no es una exposición pasiva de ideas, planteamientos y conclusiones, sino más bien, sus propuestas involucran al lector por su osadía, por su a veces hiriente humor, en un diálogo continuo y exaltado, en ocasiones exasperante, pero nunca indiferente.

Leemos así, con precisión descriptiva, que "en el filo de la navaja entre la metafísica y el realismo entrañable", se desarrolla el trabajo plástico de García Guerreo, captando en él la "épica inadvertida" de los objetos humildes, de las formas cotidianas que nos rodean silenciosas y que, a veces, se olvida su presencia.

Situado en esa corriente intimista, alterna a la "gigantomaquia de los mu" ralistas", García Guerrero - como Carlos Mérida, María Izquierdo, Frida Kahlo, Antonio Ruiz, Rufino Tamayo, Agustín Lazo, entre otros- lleva a cabo una búsqueda cuyo obejtivo principal es recuperar elementos de la cultura popular provinciana, convirtiéndolos en fuentes formales ó en el prin" cipio mismo de un lenguaje plástico. Ajena a la grandilocuencia de exaltaciones históricas, heróicas y autoafirmativas, esta corriente hurga en los rincones de la patria, pero la patria de todos los días, la de López Velarde, aromas provincianos e imágenes fijas, la hecha de costumbres y trabajos, tradiciones, vivencias y recuerdos entrañables. Así García Guerrero pinta alacenas, frutas cotidianas sobre limpios manteles o suspendidas en un espacio mágico, insectos $\mathrm{y}$ animales, pedazos de minerales, paisajes que se detienen ante nosotros con su apariencia familiar y siempre nueva. Imágenes gozosas para los sentidos - ya que no solo se ven sino se tocan, se huelen, trabajadas con una técnica pulida y preciosista dentro de un universo pictórico impregnado de una atmósfera surrealista. 
Luis García Guerrero nace en 1921 en la ciudad de Guanajuato, tierra de grandes pintores y "escenario admirable" para ejercitar la visión plástica y la sensibilidad temprana. Ambiente enrarecido por el conservadurismo de sus tradiciones, no lo es tanto en lo cultural y estético, por el contrario, hereda las riquezas artísticas de los tiempos del esplendor minero. Los paisajes, la arquitectura, los cielos y el aire luminoso capacitan al joven pintor en su aprendizaje autodidacta. Después de fallidos intentos en las carreras de arquitectura y artes plásticas, estudia leyes para complacer a su familia.

En 1949 se traslada, como tantos otros, a la ciudad de México. Sale de su pueblo, según Monsiváis, "por urgencia vital", pero en la Capital su provincianismo se acentúa.

Es hasta principios de los años cincuenta que García Guerrero consigue el salvoconducto hacia los medios artísticos: conoce a Inés Amor, quien presenta en la Galería de Arte Mexicano su obra, una pintura distinta a las corrientes por entonces vigentes, "ni académica ni de inspiración estrictamente revolucionaria". No obstante esta apertura, su trabajo como pintor no le da para vivir y requiere de otros empleos para hacerlo. El reconocimiento de García Guerrero empieza a consolidarse por los años setentas, concluye Monsiváis, aunque la crítica no ha tenido gran éxito en ubicarlo ćon precisión, debido a los "escollos que presenta una obra sin asideros anecdóticos, rigurosa interna y externamente, dedicada a la celebración de los sentidos".

Esta edición presenta láminas de gran calidad que reproducen el trabajo de García Guerrero, incluyendo títulos y medidas de cada cuadro. Al final del libro se desarrolla una cronología biográfica y una bibliografía bastante completa sobre el tema. Finalmente, se incluye una lista de las setenta y dos ilustraciones o láminas que componen la parte gráfica del libro, parte destacada por su belleza y calidad.

Julieta Ortiz Gaitán

INTER-AMERICAN MUSIC REVIEW, editor Robert Stevenson, volumen VI (Primavera-Verano de 1985), número 2 y volumen VII (Otoño-Invierno de 1985), número 1, Marina del Rey, California, 105 y 127 págs. respectivamente, rústica, $25 \mathrm{x}$ $18 \mathrm{~cm} ., 70.00$ USCy.

Los dos últimos números de la revista producida por la formidable Robert Stevenson (1916) contienen una contribución musiocológica de primer orden, ya que se publican en ellos cincuenta $y$ cinco piezas corales de diversos autores latinoamericanos que florecieron entre los siglos XVI y XVIII, en impecables ediciones con atinadas sugerencias de transposición, que permitirán a cualquier director de coro la interpretación de esta música tradicional con el conjunto a su cargo. En vista der que la mayoría de estas piezas no están disponibles fuera de diversas fuentes muy especializadas y no siempre de fácil alcance, debemos considerar esta publicación como uno más de los 
numerosos hitos musicológicos que las naciones americanas de tradición española y portuguesa deben al trabajo magnífico de Robert Stevenson, agraciado recientemente con el Premio Interamericano de Cultura "Gabriela Mistral", que fue concedido a un ciudadano de Estados Unidos por primera vez y que se justificó ante la opinión general por "el señalado aporte de toda una vida y contribución, al estudio riguroso, conocimiento y difusión de los valores culturạles que, a través de la música, distinguen al Continente Americano", enfatizando además la universalidad de su trabajo, su originalidad y la vigencia presente de su quehacer musicológico.

Los volúmenes tienen una introducción general (Hispanic American Music Treasury: 1580-1765), breve y clarificadora, que sirve de perfecto umbral para su importante contenido. Los compositores cuyas obras se han rescatado de entre siglos de polvo y olvido son: Juan de Araujo (1646-1712), activo en Bolivia; Cristóbal de Belsayaga, activo en Cuzco y Lima durante finales del siglo XVI y el principio del siglo XVII; Manuel Blasco, activo en Quito hacia el final del siglo XVII; José Cascante, activo en Bogotá durante el primer tercio del siglo XVIII; Roque Ceruti (c. 1683-luego de 1760), compositor italiano activo en Lima y Trujillo, Perú; Roque Jacinto de Echeverria, activo durante el primer tercio del siglo XVIII en la ciudad que hoy se llama Sucre; Bolivia; Antonio Durán de la Mota, activo durante el primer tercio del siglo XVIII en Potosí, Bolivia; Gaspar Fernández (c. 1570-antes de 1629), activo en Antigua, Guatemala y Puebla; Gutierre Fernández Hidalgo (1553-después de 1620), activo en Bogotá, Quito, Cuzco y La Plata (hoy Sucre); Juan García de Zéspedes, activo en Puebla durante el segundo tercio del siglo XVII; Juan Gutiérrez de Padilla (c. 1590-antes de 1664), activo en Málaga, Cádiz y Puebla; Juan de Herrera (c. 1665-antes de 1738), activo en Bogotá; Tomás de Herrera, activo entre 1611 y 1620 en Cuzco; Francisco López Capillas (c. 1615-1673), activo en Puebla y la ciudad de México; Manuel Thadeo de Ochoa, activo en Puebla durante la primera mitad del siglo XVIII; Juan Mathias, activo durante el segundo tercio del siglo XVII en Oaxaca; José de Orejón y Aparicio (1706-1765), activo en Lima; Tomás Pascual, activo durante el final del siglo XVI y principio del XVII en lo que hoy es Huehuetenango, Guatemala; Juan Pérez Bocanegra, activo en Cuzco y Andahuaylillas, Perú, durante el mismo período que Tomás Pascual; Antonio de Salazar (c. 1650-1715), activo en Sevilla y en la Catedral de México; Duyn Sjntujguy, o sea Manuel de Quiroz, activo en Antigua, Guatemala, durante el segundo tercio del siglo XVIII; Tomás de Torrejón y Velasco (1644-1728), activo en Lima y Trujillo; Pedro Ximénez, activo durante el segundo tercio del siglo XVII en Lima y Manuel de Zumaya (c. 1678-1756), activo en la Catedral de México y en Oaxaca.

La evidente relación de estos volúmenes de la IAMR con Renaissance andBaroque Musical Sources in the Americas (Washington, 1970), del propio Stevenson, y con la Antología de la música colonial en América del sur (Santiago de Chile, 1974), de Samuel Claro Valdés (1934), no hacen sino enfatizar la magna labor musicológica de Stevenson, directamente ligada, en este campo, con sus previas publicaciones: Foundations of New World Opera with a transcription of the earliest extant American Opera (Lima, 1973), Christmas Music from Baroque Mexico (Berkeley, 1974), Seventeenth-Century 
villancicos from a Puebla convent archive transcribed with optional added parts for ministriles (Lima, 1974) y Latin American Colonial Music Anthology (Washington, 1975).

Stevenson, especializado en un nivel de investigación profunda que no tiene parangón en el siglo XX dentro de su campo de especialidad, entrega en estos volúmenes de la IAMR, una contribución de inmenso peso específico, una más del impresionante monumento de investigación musical que ha construido a to largo de una vida entera dedicada al trabajo tenaz y a la búsqueda creativa y obstinada.

Jorge Velazco

INTER-AMERICAN MUSIC REVIEW. editot Robert Stevenson, volumen VII, Primavera-Verano de 1986, número 2, Marina del Rey, California, 125 págs., $25 \mathrm{x}$ $18 \mathrm{~cm} ., 10.00$ USCy.

En este número de la revista, encontramos una muy respetable cantidad de información bibliográfica, que comprende la reseña de diez publicaciones que van desde la música de Guatemala en el siglo XVIII hasta el diccionario bibliográfico de músicos africanos y afroamericanos, pasando por la zona de la historia de la música española escrita por Samuel Rubio (desde el Ars nova hasta el 1600) y el primer tomo de las obras musicales de Carlos Patiño. También hay un homenaje al peruano adoptivo Rodolfo Holzmann por su septuagésimo quinto aniversario y dos necrologías con motivo del fallecimiento del Padre Samuel Rubio, eminente musicólogo español, fundador y primer presidente de la Sociedad Española de Musicología y uno de los investigadores más destacados en el campo de la pólifonía clásica y en el de la música de la Edad Media y el Renacimiento.

Sin embargo, es la sección de artículos (dedicada a Franz Liszt) la que brilla con singular esplendor, a causa - desde luego- del riquísimo tesoro de información sistematizada, que hasta el momento había estado fuera del alcance general y cuyo interés, tanto musical como histórico, rebasa el usual enfoque de las revistas musicales que circulan corrientemente en América. Hay un inventario hecho por John Emerson de la Colección Hugo Mansfeldt (1844-1932) que posee la Universidad de California en la Biblioteca Musical de Berkeley. Se publica también una interesantísima carta de Amy Fay (18441928), con el título de Horas musicales en Weimar con los pianistas del futuro, originalmente aparecida en el Boston Daily Advertiser, en 1876. Todo esto completa los tres artículos medulares acerca de Liszt que aparecen en este volumen.

Los ensayos en cuestión fueron hechos por el gran Robert Stevenson, y confirman -una vez más- el nivel supremo al que ha llegado este musicólogo, uno de los más eminentes investigadores que ha dado el mundo, cuya labor no tiene par en su área de trabajo. El primero, Liszt in the Iberian Penninsula, 1844-1845, se refiere a la hoy histórica gira del artista húngaro por España y Portugal y cumple con las características de búsqueda profunda, 
enjundioso análisis, impecable síntesis, revelaciones de hechos importantes, pero desconocidos, que arrojan nueva luz sobre personajes y obras, escrito en el fluido, expresivo y elegante inglés que ha distinguido siempre a Stevenson. Algunos comentarios de Liszt, exhumados y sistematizados por Stevenson, como los referidos al valor pecuniario de los regalos recibidos por el virtuoso húngaro de la realeza española y portuguesa, parecen confirmar la teoría expuesta por Ernest Newman (1868-1959), en su obra The Man Liszt (Londres, 1970), acerca de la verdadera y extraña naturaleza personal del ilustre compositor y la falsificación y ocultamiento de su personalidad, realizados por él mismo y sus discípulos. Esa fascinante teoría, que linda con un enfoque psicoanalítico del hombre, parece reforzarse con algo de lo expuesto por Stevęnson, además de la luz que las investigaciones del musicólogo norteamericano proyectan sobre una de las más importantes actividades concertísticas de Liszt, obviamente ligada estrechamente a la historia musical iberoamericana. Esta luz nos permite observar de cerca las actuaciones de personajes de primera importancia, como el tenor Enrico Tamberlick (18201889), el famoso pedagogo Hilarión Eslava (1807-1878), Isabel II de España (1830-1904) y María II de Portugal (1819-1853), así como enfocar a quienes hacían el ambiente mụsical y cultural de la península ibérica en la mitad del siglo XIX, cuyas figuras se han vuelto extremadamente borrosas en el curso de los años: el pianista Juan María Güelbenzu (1819-1886), alumno de Emile Prudent (1817-1863) y pianista de la corte; el primer profesor de piano del entonces recientemente fundado Real Conservatorio de Música de Madrid, Pedro Albéniz (1795-1855), discipulo de Henri Herz (1803-1888) y Frédéric Kalkbrenner (1785-1849); Sebastián Iradier (1819-1865), cuya canción El arreglito fue citada en la "Habanera" de Carmen; el famoso compositor de zarzuelas Joaquín Gaztambide (1822-1870); el compositor de ópera Joaquín Espín y Guillén (1812-1881), frecuente consultor. de Rossini y Verdi; la compositora Paulina Cabrera y Martínez de Ahumada (1822-después de 1866); Eugenio Gómez (1802-1871), organista de la Catedral de Sevilla y los compositores Manuel Inocêncio Libertão dos Santos (1805-1887) y Francisco Antonio Norberto dos Santos Pinto (1815-1860). Todos estos músicos vuelven a vivir en la brillante narración de la investigación de Stevenson, quien además nos habla de los fabulosos ingresos de Liszt por concepto de la gira (sólo en Madrid se embolsó la entonces increíble cantidad de ocho mil francos por cuatro conciertos).

El segundo artículo, de fascinante atractivo para este país, se titula Liszt in Mexico, 1840-1911 y consiste de una sistematización de la influencia lisztiana en México, de las expresiones de interés de los mexicanos en su obra y su persona y de la forma como esta nación y su historia se proyectaron en las actividades de Liszt, con inclusión de los dos polos constituidos por su atesoramiento del diploma que lo acredita como miembro honorario de la Sociedad Filarmónica Mexicana (1875) y la Marcha fúnebre en memoria de Maximi. liano 1, Emperador de México (1867). La lúcida exposición de Stevenson de actividades musicales alrededor de Liszt en México, es otro más de los logros musicológicos del gran Stevenson.

E1 siguiente artículo Liszt "Favorite" California Pupil: Hugo Mansfeldt, (1844-1932) nos enfrenta con una de las mảs curiosas figuras de la música 
del siglo XIX, tan atractiva y novelesca como Ole Bull (1810-1880) ○ Louis Moreau Gottschalk (1829-1869). Es, desde luego, uno de esos estudios alla Stevenson, cuya proporción de investigación profunda, sistematización analítica, juicio histórico, perspectiva estética y enfoque profesional, es abrumadora si se compara con el usual trabajo de investigación en esta rama. También tiene las constantes de originalidad y amena exposición a que Stevenson nos tiene acostumbrados. Ante los resultados aplastantes, en calidad y cantidad, que surgen de su pluma como si fueran composiciones hechas por Mozart, no queda sino asombrarse y realizar una profunda y sincera inclinación ante la obra de una mente que representa la genialidad y en el trabajo de investigación musicológica.

Jorge Velazco

Comunicación Visual. Revista de arte y diseño. Año I, No. 6. México, Nov.-Dic., 1987.

El sexto número de la revista de arte y diseño, Comunicación Visual, correspondiente a los meses de noviembre y diciembre de 1987, representa el mejor testimonio para verificar el profesionalismo de sus responsables, palpable tanto en los objetivos que originalmente se propusieron como miembros del Consejo Editorial, como en el trabajo desempeñado hasta ahora para ir cumpliendo los mismos.

Cabe advertir que en un principio el carácter independiente de la revista, subrayado desde el número de apertura (enero-febrero de 1987), pudo interpretarse como la señal anticipada de un inminente naufragio: todos sabemos de los peligros que implica esa palabra en el ámbito cultural del país. Por si fuera poco, la publicación se presentó como el órgano de difusión del Centro de Desarrollo de la Comunicación Visual, que a su vez es una institución independiente. Los pronósticos, pues, no eran los más favorables, y los integrantes del Consejo editorial estuvieron conscientes de ello. En una exposición de motivos lo hicieron ver, pero también, ahí mismo, expresaron su entusiasmo y una claridad de perspectiva, propia de un criterio que se antoja necesario para comprender y difundir las artes visuales en estos tiempos.

En dicho texto la revista se comprometió a mantener secciones referentes a las artes visuales contemporáneas, los productores de arte y la comercialización de su obra. También, otras relativas a las relaciones entre las artes y la tecnología, la educación, el arte popular y las disciplinas museográficas, el disef̂́o gráfico, el arte textil urbano, y otras sobre producciones esceñográficas. Asimismo, se incluyen en cada número crónicas sobre exposiciones, libros y revistas, y las actividades del centro editor de esta publicación.

Un año después, es posible evaluar los resultados. Con admiración y cierta sorpresa nos percatamos de que cada una de las promesas hechas en el virtual repertorio temático se han cumplido. Los colaboradores son, por lo general, personas formadas en el seno de instituciones y de grupos de estudio avocados a la investigación artística, que confían más su pluma a la búsqueda objetiva de información que a las tentaciones de la musa. El espíritu de la revista se 
orienta a lo primero y pretende en cada publicación proyectar una imagen amable y sobria, advertible tanto en el diseño como en la estructuración del contenido (aunque es de lamentar la fusión de las secciones de diseño y de arte contemporáneo).

$\mathrm{Y}$ del mismo modo en que es tangible la evolución de la factura de la revista (aumento de páginas, mejor selección de color en la fotografía de la portada y mayor niditez en las fotografías en blanco y negro, mejoras en la topografía y en el diseño, empleo a partir del tercer número de papel de distinto color), también es fácil atestiguar el desarrollo del Centro como espacio serio de instrucción, donde se realizan cursos destinados a la enseñanza de la teoría del arte, entre otros.

La sección correspondiente al arte contemporáneo abarca diversos análisis teóricos sobre las corrientes y tendencias surgidas a partir de 1970. Los títulos hasta ahora comprendidos son, por orden de publicación, los siguientes: "La plástica actual en México", por Carlos Blas Galindo; "Una especulación sobre nuestra pintura actual", por Manuel Centeno; "Una década emergente", por Emma Cecilia Garcia, y "El libro como objeto artístico", por Jesús Zárate Rivera (los números 5 y 6 no incluyeron esta sección). En virtud de la novedad de los autores citados, conviene advertir al virtual lector que cada uno de ellos se apega, como es natural, a un bagaje de información bastante amplio y que guarda estrecha relación con su especialidad en el trabajo, desempeñado en instituciones culturales.

La comunión de sus experiencias como artista, funcionario y crítico de arte, hace de Carlos Blas Galindo una persona sumamente autorizada para abordar el tema del arte desde distintas perspectivas. Su artículo así lo demuestra y representa un buen principio para la revista, interesada por mantener lazos muy estrechos entre la teoría y la muy rica y compleja realidad del arte actual. El texto se ocupa de situar las actividades plásticasi en el contexto económico, social y cultural del país, para lo cual se centra en los aspectos de la producción, las "funciones múltiples y cambiantes del arte", así como en otras referidas a la difusión y promoción de distintos medios.

En esta misma línea, Manuel Centeno comparte con su colega el mérito de adentrarse en el ambiguo panorama del arte actual, sin caer en los manidos lugares comunes alusivos al "eclecticismo posmodernista", al "arte ensimismado", y en otros más que plagan la literatura sobre arte en nuestros días. Su punto de vista, desarrollado a manera de exégesis, invita al lector a analizar la ruptura que estableció la entonces llamada " joven pintura" con el muralismo mexicano. El autor se expresa a través de un lenguaje pródigo en referencias lingüísticas y filosóficas, que a pesar de no apoyarse en otras de carácter histórico, consigue ubicar al lector en el tiempo de aquella confrontación plástica. Asimismo, la interpretación de Centeno sobre lo novedoso de las poéticas visuales contemporáneas con respecto a las que marcaron la ruptura, aparte de ser fresca, posee un contenido digno de tomarse en cuenta al manejarse clasificaciones de hondo arraigo en la década de los años sesenta, como la de nueva figuración, y algunas relacionadas con las tendencias abstractas, por ejemplo.

Una recomendación nos gustaría hacer a los autores citados, en el sentido de que en futuros trabajos amplíen algunas observaciones. La opinión que 
Carlos Blas pudiera expresar acerca de la permeabilidad de las artes visuales mexicanas, sería, sin duda de las más consistentes en el medio. Seguros de ello, no somos pocos quienes esperamos el desarrollo del siguiente comentario, aparecido en su artículo ya mencionado; dice: "En cuanto a las temáticas o contenidos, persisten actitudes, casi totalmente generalizadas, de evitar la alusión a situaciones locales, de no remitir al entorno natural o social y de omitir el tratamiento explícito de problemáticas propias, así como un afán de imitar e imponer patrones externos".

Por su parte, Manuel Centeno quizá podría enriquecer su enfoque al apoyarse en datos concretos; incluso, el análisis de la obra de un autor determinado - como la de Manuel Felguérez, a quien considera en su textosería muy apropiado para el caso.

La publicación del trabajo de Emma Cecilia García, curadora del Museo de Arte Moderno y del Museo Universitario del Chopo, significa un doble mérito para Comunicación Visual. Primero: por la calidad del artículo en sí; segundo, por consignar una exposición de indudable importancia cuya realización en un foro universitario atenta contra su trascendencia en nuestro ámbito cultural. En efecto: como sabemos, en México muchos de los acontecimientos artísticos que no ocurren al amparo de las instituciones directamente dependientes del Estado, corren el riesgo de no existir en la memoria de nuestra cultura. Díganlo si no los testigos de tantas muestras efectuadas en la Casa del Lago, la Galería Aristos, el Palacio de Minería y el propio Museo Universitario del Chopo.

La exposición se tituló "Una década emergente" y se llevó a cabo en 1984. A ella fueron invitados cuarenta y dos artistas nacidos durante la década de los años cincuenta. Su objetivo era el investigar y documentar el trabajo de una generación que se gestó en un periodo caracterizado por la experimentación individual y de grupo, al margen de los soportes técnicos tradicionales.

La autora advierte desde un principio sobre las dificultades de "hablar de corrientes o estilos específicos dentro de la joven plástica mexicana", y también llega a una conclusión que, de acuerdo a lo que recordamos de la muestra, nos parece acertada; sobre el conjunto de la obra opina: “. . . dentro de su diversidad, muestra que la preocupación de los artistas tiende a la solución de aspectos formales más que al análisis de problemáticas políticas y sociales en un momento de crisis nacional e internacional. Los jóvenes artistas exploran el formalismo, y en pocas ocasiones sus planteamientos trascienden, de manera netamente renovadora, al de stus maestros". Cuando Emma Cecilia García se refiere al formalismo es probable que aluda a la muy clara intención de Arnold Belkin -entonces director del museo- de rescatar el valor de las expresiones lineales, opacado durante un tiempo por el pictoricismo sustentado por las tendencias informarles. Con este fin se exhibieron textos reivindicativos del dibujo como disciplina plástica; recordamos al respecto las célebres palabras de Durero y otras muy hermosas del artista italiano Rico Lebrun.

Pero tal vez el mayor mérito de la historiadora consista en saber describir la obra. Su empleo del léxico más o mehos reciente de la crítica de arte es apropiado y cumple por eso una función didáctica al publicarse, con todo y que no pocos artistas de entonces ya han cambiado muchos de sus lineamientos. 
Jesús Zárate Rivera aborda, por su parte, el tema del libro como objeto artístico. Su artículo es más bien una fluida conversación con Yani Pecanins, promotora junto con Gabriel Macotela de este tipo de materiales en El Archivero (espacio dedicado a la documentación, exhibición y venta de libros de artistas, ubicado en la ciudad de México). Por dicha plática nos enteramos de que los libros de artista están destinados, por lo general, a trasmitir lenguajes artísticos en base a imágenes que en ocasiones se apoyan también en el lenguaje escrito. Su familiaridad con el libro-objeto es estrecha, aunque éste cifra en buena medida sus valores artísticos en las propiedades materiales que como objeto posee.

La importancia concedida al diseño en sus múltiples ramas es otra loable función de la revista. Con todo y no ser la única abocada a ello, sí es de las que ofrecen mejores materiales y una proyección fundamentalmente didáctica. El diseño, aunque parezca mentira, es una de las disciplinas menos favorecidas en México por estudios teóricos y por la divulgación de los que hay. Incluso, la distinción que priva en los centros de enseñanza (incluso los universitarios) entre teoría y práctica es radical; la primera se enseña de manera muy general y con una actitud de "querer librar el bulto".

Asimismo, las secciones convencionales, por así llamarlas, no dejan de hacer valiosas aportaciones. Tanto la sección de libros y revistas como las destinadas a reseñar exposiciones y diversos acontecimientos artísticos cumplen, en general, con el compromiso contraído con el lector de aparecer cuando la publicación es de veras reciente o cuando el evento puede presenciarse todavía. Por otra parte, las secciones que ocupan asuntos poco conocidos, pero que forman parte de nuestra cultura artística, presentan notables realizaciones y abren caminos en terrenos poco explorados, sobre todo en los renglones de temas jurídicos y de mercado.

A pesar de la grave situación por la que atraviesa el país, no han dejado de aparecer nuevas publicaciones que se esfuerzan por valorar las artes plásticas al margen de esquemas y criterios convencionales; Comunicación Visual, por su parte, cifra sus méritos en la capacidad de saberse servir de todo lo que representa ser una revista independiente.

Luis Rius Caso 
DOI: http://dx.doi.org/10.22201/iie.18703062e.1988.59.1414 


\section{BIBLIOGRAFIA MEXICANA DE ARTE - 1987}

XAVIER MOYSSÉN

Manifiesto aquí mi sorpresa ante el importante número de libros dedicados a las artes, que se publicaron en México durante 1987, sorpresa originada por la situación económica que desde años atrás priva en el país; el saldo ha sido favorable, como se verá por los títulos agrupados por secciones, lo cual indica, por otra parte, que pese a todo la cultura en sus diversas manifestaciones no se detiene.

Año con año aumenta la producción de libros dedicados a la fotografía, un arte que posee valores y medios propios para expresarse y que en México cuenta con singulares maestros. Como si los distintos editores se lo hubieran propuesto, en 1987 la fotografía de paisajes ocupó primordialmente su atención, sobre todo para publicarlos con reproducciones a color; gracias a ello se pone de manifiesto lo prodigioso y múltiple que es el paisaje de la Repíblica; al respecto, un libro sorprendente es el titulado Los grandes abismos de México, por lo insólito de los espectáculos stibterráneos que entrega a nuestra yista, a nuestro conocimiento, mediante las fotografias que contiene.

México es un país en el que el gusto y la práctica por la pintura están fuera de discusión, como en años anteriores, un número considerable de vo. lúmenes ocupa esta expresión artística. Los estudios de investigación y análisis sobre los pintores y lo que producen, sobresalen por sus propios méritos; asimismo acontece con los libros dedicados a inventarios de obras, catálogos y bibliografías, o los que contienen recopilaciones de textos de difícil consulta, como son en muchas ocasiones los escritos por los propios artistas.

En los libros de arte cuya finalidad específica es la difusión de las obras y sus valores estéticos, la calidad de las reproducciones debe ser factor de exigencia principal, sobre todo en los dedicados a las obras de los pintores; en este sentido las empresas que trabajan en la ciudad de México, en la impresión esmerada de este tipo de libros, están a la altura de las mejores del extranjero, incluso sus méritos se les han reconocido en certámenes internacionales; entre esas empresas sobresalen Litógrafos Unidos, Offset Setenta, Madero, e Impresora Formal.

Hoy día todo indica que la producción de costosos y atractivos libros dedicados a las artes le está conferida, por razones obvias, a las empresas de la iniciativa privada o a las instituciones oficiales, en cambio, otras editoriales se ven impedidas de realizar publicaciones semejantes; en el caso de aquéllas sus ediciones no son venales, sino que las hacen para cumplir con sus compromisos e intereses particulares; enhorabuena que se pueda contar con su esfuerzo, sin embargo, no dejo de considerar que alcanzarán un éxito mayor si los textos de esos libros los encargaran a quienes están capacitados para hacer aportaciones trascendentes, mediante la autoridad de sus conocimientos en las distintas materias que tratan. 


\section{ARTE PREHISPANICO}

Gendrop, Paul, Compendio de Arte Prehispánico, México, Editorial Trillas, 1987.

Gutiérrez Solana R., Nelly, la serpiente en el arte mexica, México, UNAM, 1987.

Matos Moctezuma, Eduardo, Cacaxtla, México, CITICORP, 1987.

WinNING, Hasso voN, La iconografía de Teotihuacan. Los dioses y los signos. Dos volúmenes, México, UNAM, 1987.

\section{ARTE COLONIAL}

ANAYa LaRIos, José Rodolfo, Historia de la escultura queretana. Querétaro, Qro., Universidad Autónoma de Querétaro, 1987.

BaIRD JR., Joseph, Los retablos del siglo XVIII del sur de España, Portugal y México, México, UNAM, 1987.

Cervantes, Enroue A., Loza blanca y azulejo de Puebla. Edición facsimilar. Gobierno del Estado de Puebla, Puebla, Secretaría de Cultura, 1987.

Cortina Portilla, Manuel, El caballo de bronce que camina (Sobre el monumento a Carlos V, de Manuel Tolsá), México, CONSA. Distribuidora Ford, 1987.

Díaz, MARCo, Antigua Villa de Carrión. Arquitectura religiosa y civil. Puebla, Centro Regional de Puebla, INAH-SEP, 1987.

Merlo Juárez, Eduardo, Templo de Nuestra Señora de la Soledad de Puebla. Puebla, Pue., 1987.

Puebla, Ayer y Hoy. Centro Histórico. Puebla, Gobierno del Estado de Puebla, 1987.

Rrvera, Diego DE, Poética descripción de la pompa plausible que admiró esta nobilisima ciudad de México, en la sumptuosa dedicación de su hermoso, magnifico y acabado templo, celebrada, jueves 22 de diciembre de 1667 años. Edición, estudio preliminar y notas de Efraín Castro Morales. Puebla, Ediciones Altiplano, 1986.

Ruiz Gomar, Rogelio, El pintor Luis Juárez. Su vida y su obra, México, UNAM, 1987.

Sánchez Navarro de Pintado, Beatriz, Marfiles cristianos del Oriente en México. México, Fomento Cultural Banamex, A. C., 1986.

Sescosse, Federico, San Agustín de Zacatecas. Vida, muerte y resurrección de un monumento. Zacatecas, Sociedad de Amigos de Zacatecas, A. C., 1986.

VARgas Lugo, Elisa, las portadas religiosas de México. Segunda Edición. México, UNAM, 1986.

Varios autores, Catálogo de pintura del Museo del Carmen. México, Casa de Bolsa Probursa, 1987.

Varios autores, Los vascos en México, y su Colegio de Las Vizcainas. México, Tabacalera Mexicana, S. A. de C. V., 1987.

VARIos AUTOREs, Imágenes Guadalupanas. Cuatro Siglos. Catálogo exposición. Centro Cuitural Arte Contemporáneo, México, 1987. 
VARIos AUTORES, Querétaro rescate patrimonial. Querétaro, Gobierno del Estado de Querétaro, 1985.

Victoria, José Guadalupe, Pintura y sociedad en Nueva España. Siglo XVI. México, 1986.

\section{ARQUITECTURA}

ANDA, EnRIQUe X. DE, Evolución de la arquitectura en México. Epocas prehispánica, virreinal, moderna y contemporánea. México, Panorama Editorial, 1987.

ANDA Alanis, EnRIQue X. DE, Le Corbusier y su influencia en la arquitectura moderna mexicana. Exposición Fotográfica. Museo Nacional de Arquitectura. México, INBA-SEP, 1987.

Díaz Infante N., Juan José, Del Dolmen a la Kalikosmia. México, 1987.

Díaz Infante visto por Díaz Infante. Introducción de Mathías Goeritz, Ignacio Maya Gómez y Jaime Torres Palacios. Comentarios Richard Atamián. Arquitectura J. J. Díaz Infante N. Fotografías J. J. Díaz Infante C. México, 1987.

Gutiérrez, Miguel Ángel, Diaz Infante visto por Miguel Ángel. México, 1987.

Guzmán Urbiola, Xavier y JaIme Moreno Villarreal, la habitación interminable. México, Universidad Autónoma Metropolitana-Xochimilco, 1987.

López Morales, Francisco Javier, Arquitectura Vernácula en México. México, Editorial Trillas, 1987.

Negrín, Chel y Tulio Fornari, El mensaje arquitectónico. México, Universidad Autónoma Metropolitana, 1987.

Pacheco, Cristina, Imágenes. Renovación Habitacional Popular. México, $1986 / 1987$.

Tovar De Teresa, Guillermo, La Ciudad de México y la utopia en el siglo XVI. México, Seguros de México, S. A., 1987.

Ramírez Vázoutz, Pedro, Charlas de... México, Universidad Autónoma Metropolitana, 1987.

Renovación Habitacional. Testimonio. Sociedad de Arquitectos Mexicanos, Colegio de Arquitectura y Urbanismo, México, 1987.

VARIos autores, La ciudad. Concepto y obra (VI Coloquio de Historia del Arte). México, UNAM, 1987.

VARIOS AUTORES, La construcción en el arte. México, Cámara Nacional de la Industria de la Construcción, 1987.

José Villagrán, Catálogo exposición en el Museo Nacional de Arquitectura, Palacio de Bellas Artes. Con una Introducción "José Villagrán y la Escuela Mexicana de Arquitectura", por Ramón Vargas Salguero, México, INBA, 1987. 


\section{ESCULTURA}

Silva, Federico, Una experiencia personal. La escultura y otros menesteres. México, UNAM, 1987.

Varios aUtores, Giacometti. Catálogo exposición en el Centro Cultural Arte Contemporáneo, A. C., México, Fundación Cultural Televisa, A. C., 1987.

\section{FOTOGRAFIA}

Alatorre, Antonio, Casa Santa. Fotografías de Rafael Doniz. México, Fondo de Cultura Económica, 1986.

Domeco, Brianda, Voces y rostros del Bravo. Fotografías de Michel Calderwood. México, Casa de Bolsa INVERLAT, 1987.

Gutírrez, LudivinA, Dialo-grafos con Miguel Femat. Xalapa, Ver., Universidad Veracruzana, 1987.

Poniatowska, Elena, Héctor García. México sin retoque. México, UNAM, 1987.

Poniatowska, Elena, Estancias del olvido (Haciendas Pulqueras). Pachuca, Gobierno de Hidalgo, 1987.

Poniatowska, Elena, Tlacotalpan. Fotografías de Mariana Yampolsky. Jalapa, Gobierno del Estado de Veracruz, 1987.

ReYES, AURELio DE los, Medio siglo de cine mexicano (1890-1947). México, Editorial Trillas, 1987.

SAMperio, Guillermo, Lázaro Blanco. Luces y tiempos. Col. Río de Luz, México, FCE, 1987.

Descubriendo el mundo maya. Siglo XIX. Introducción de Mario de la Torre. Fotografías de Osbert Salvin y Desiré Charnay. México, Celanese Mexicana, S. A., 1987.

Los grandes abismos de México. Prólogo de Harry Mõller, Introducción de Carlos Lazcano, México, Inversora Bursátil, 1987.

El insólito paisaje mexicano. Fotografías de Enrique Franco Torrijos. Textos de E.F.T., y Andrés Henestrosa. México, Nacional Financiera, $198 \%$.

México visto desde las alturas. Fotografías de Michel Calderwood, prólogo de José Luis Martínez, textos de Claudia Canales. México, Fomento Cultural Banamex, A. C., 1987.

\section{GRAFICA}

Moyssén, Xavier, La iitografia en México. Casimiro Castro. México, Grupo Apicsa, 1987.

Paz Octayio, Creencia. Con tres serigrafias de Amaldo Coen. México. Ediciones Papeles Privados, 1987.

Trbol, Raquel, Gráficas y neográficas de México. México, SEP, 1987.

Trbol, Raquel, "Las nuevas técnicas gráficas de Rufino Tamayo", Catálogo exposición Tamayo 70. Obra gráfica. México, INBA-SEP, 1987.

Vargas Lugo, Elisa, et al, Bosquejos de México. Siglo XIX. Colección de grabados y litografías del Siglo XIX del Banco de México. México, 1987. 
50 años Taller de Gráfica Popular. 1937-1987. Catálogo exposición. Museo del Palacio de Bellas Artes. Museo Nacional de la Estampa, Galería José María Velasco. México, INBA, 1987.

\section{PINTURA CONTEMPORANEA}

Alanís, Judith y Sofía URrutia, Rufino Tamayo. Una cronología/1899. 1987. México, INBA-SEP, 1987.

Corredor-Matheos, José, Tamayo. Barcelona, Ediciones Poligrafía, 1987.

Chapa, Martha, Cómo se cocina una pintura. Introducción de Andrés Henestrosa. México, 1987.

Debroise, Oliver, Antonio Ruiz. El Corcito. Con una antología de textos de varios autores. México, DIMART, 1987.

Debroise, Olivier y Teresa del CoNde, Enrique Guzmán 1952-1986. MéxiCO, INBA-SEP, 1987.

Debroise, Olivier, et al, Arturo Rivera. El rostro del dolor. México, SEP, 1987.

García Ascot, Jomí, Tres pintores. Pablo Amor, Oscar Guzmán, Gabriel Macotela. México, PROMEXA, 1987.

García PONCE, JuAN, Una lectura pseudognóstica de la pintura de Balthus. México, Ediciones del Equilibrista, 1987.

GONZÁLEZ MATUTE, LAURA, Escuelas de pintura al aire libre y centros culturales de pintura. México, CENIDIAP, INBA, SEP, 1987.

Hí JaR, AlBerto, Leticia Ocharán. Eros y Tánatos. Lo simple y lo complejo. México, UNAM, 1987.

IAMIs, Rauda, Frida Kahlo. México, Edivisión, 1987.

López Domínguez, Leonor y Aurelio Asiain, Julio Ruelas. México, Casa de Bolsa CREMI, 1987.

LuNA, ANdrés DE, Arnold Belkin. México, UJNAM, 1987.

Monsivárs, Carlos, García Guerrero. México, PROMEXA, 1987.

Olivares Iriarte, Bernardo, Album Artístico, 1879. Puebla, Gobiemo del Estado de Puebla, Secretaría de Cultura, 1987.

Ortiz Macedo, Luis, Nuestra Pintura. III. México, Seguros América, 1987.

RAMírez, FAUSTo, Notas para una nueva leciura de la obra de Saturnino Herrán. Texto del catálogo de la Exposición Nacional de Homenaje a Saturnino Herrán. 1887-1987. México, INBA, 1987.

Rico, ARACEli, Frida Kahlo. Fantasia de un cuerpo herido. México, Plaza y Valdés, 1987.

Rodríguez, Anton1o, Diego Rivera. Pintura Mural. México, Fondo Editorial de la Plástica Mexicana, 1987.

Saavedra, Manola y Carlos Landeros, Corzas. México, Pemex, Fondo Edi. torial de la Plástica Mexicana, 1987.

Tibol, Raquel, Textos de Rufino Tamayo. Recopilación, prólogo y selección de viñetas por... México, UNAM, 1987.

Tibol, Raquel, Confrontaciones. El creador frente al público. México, UAMAzcapotzalco, 1987. 
Varios autores, Miguel Covarrubias. Exposición homenaje. México, Centro Cultural Arte Contemporáneo, A. C., 1987.

Varios AUTOREs, Diego Rivera en Palacio Nacional. Obra mural. Méxica, Secretaría de Hacienda y Crédito Público y de Programación y Presupuesto, 1987.

VARIos Autores, Rufino Tamayo 70 años de creación. Catálogo Exposición Nacional. México, INBA-SEP, 1987.

Varios aUtoRes, Rufino Tamayo. Antología crítica. México, CREA y Editorial Terranova, 1987.

Escritos de Carlos Mérida sobre arte: El muralismo. Selección de textos y cronologia: Xavier Guzmán, Alicia Sánchez Mejorada de Gil, Leticia Toires Carmona y Armando Torres Michua. México, INBA, SEP, 1987.

VARTOS AUTORES, La mujer mexicana en el arte. México, BANCRESER, 1987.

URANGa López, El tema campesina en la pintura de Pablo O'Higgins. México, Universidad Autónoma Chapingo, 1987.

ZaMora, Martha, Frida. El pincel de la angustia. México, Edición de la autora, 1987.

Diego Rivera y sus discípulos. Arturo García Bustos, Arturo Estrada, Rina Lazo. Textos de varios autores. Catálogo de Exposición. México, S.T.C./ Metro, 1987.

Leo Castelli y sus artistas. Catálogo exposición. Centro Cultural Arte Contemporáneo, A. C., Textos de Calvin Tomkins, Robert Pincus-Witten, Judith Goldman. Entrevista Mary Jo Marks/Leo Castelli. México, Fundación Cultural, A. C., 1987.

De dioses y héroes. La Mitología clásica ayer y hoy. Catálogo exposición Museo de San Carlos. Texto de Teresa del Conde. México, INBA-SEP, 1987.

\section{VARIOS TEMAS}

Arte Funerario. Coloquio Internacional de Historia del Arte. Dos volúmenes. México, UNAM, 1987.

EsPinosa, ELIA, L'Esprit Nouveau. Una estética moral purista y un materialismo romántico. México, UNAM, 1987.

Fernández, Martha, La Ciudad de México. De Gran Tenochtitlan a mancha urbana. México, Departamento del Distrito Federal, 1987.

Fernández Miguel Ángel, Historia de los museos de México. México, Pro motora de Comercialización Directa y BANAMEX, 1987.

García Canclini, Néstor, La producción simbólica. Teoría y método en sociología del arte. Tercera edición, México, Siglo Veintiuno Editores, 1987.

Gual, Enrique F., El arte de estudiar el arte. Presentación de Luis Ortiz Macedo. México, INBA-SEP, 1987.

Gutiérrez, Ludrvina, Hacia dinámicas creativas en televisión de danza. Xalapa, Ver., Universidad Veracruzana, 1986.

Gutí́rRez, Ludivina, Plástica y retorno a la unidad. Xalapa, Ver., Universidad Veracruzana, 1986.

Lowe, Donald M., Historia de la percepción burguesa. México, F.C.E., 1986. 
Manrique, Jorge Alberto y Teresa del Conde, Una mujer en el arte mexicano. Memorias de Inés Amor. México, UNAM, 1987.

Paz, Octavio, Los privilegios de la vista. Arte de México. Tomo III de México en la obra de ... . México, F.C.E., 1987.

Rosales Ayala, Silvano Héctor, Tepito arte acá (Ensayo de interpretación de una práctica cultural en el barrio más chido de la ciudad de México). México, UNAM, 1987.

SchmilchucK, Graciela, Museos: Comunicación y educación. Antología comentada. México, CENIDIAP, INBA-SEP, 1987.

SCRUton, Roger, La experiencia estética. México, F.C.E., 1987.

Toussaynt, Manuel, Folklore de Puebla y los poblanos. Puebla, Gobierno del Estado de Puebla, Secretaría de Cultura, 1987.

Vallier, Dora, El arte por dentro. Conversaciones con Braque, Léger, Villon, Miró y Brancusi. México, F.C.E., 1987.

Varios autores, Del carnaval a la Academia. Homenaje a Ida Rodríguez Prampolini. México, Editorial Domés, 1987.

VARIOS AUTORES, Los estudios sobre el arte mexicano. Examen y prospectiva. México, UNAM, 1986.

El público como propuesta. Cuatro estudios sociológicos en museos de arte. Por Esther Cimet, Martha Dujovne, Néstor García Canclini, Julio Gullco, Cristina Mendoza, Francisco Reyes Palma y Guadalupe Soltero. México, CENIDIAP, INBA-SEP, 1987.

La tejedora de vida. Colección de trajes de Banca Serfin. México, 1987.

\section{MUSICA}

Díaz Du-Pond, Carlos, La ópera en México de 1924 a 1984. Segunda edición. México, UNAM, 1986.

Estrada, Julio (editor). La música de México. III Antología. 1-Período virreinal. México, UNAM, 1987.

Estrada, Iulio (editor). La música de México. III Antología. 2-Período de la Independencia a la Revolución. México, UNAM, 1987.

MendozA, VICEnte T., Estudio y clasificación de la música tradicional hispánica de Nuevo México. México, UNAM, 1986.

\section{REVISTAS}

Anales del Instituto de Investigaciones Estéticas, vol. XV, Nứm. 58. México, UNAM, 1987.

Artes plásticas. Revista de la Escuela Nacional de Artes Plásticas, México, UNAM, 1987.

Boletin CENIDIAP. (Centro Nacional de Investigación, Documentación e Información de Artes Plásticas). Núm. 1. Dedicado a Diego Rivera. MéxiCo, INBA-SEP, 1987.

Comunicación Visual. Revista de arte y diseño. México, Centro de Desarrollo de la Comunicación Visual, A. C., 1987. 
Cuadernos de arquitectura mesoamericana. Número 9 dedicado a la "Presencia prehispánica en la arquitectura moderna". México, UNAM, 1987.

México en el arte. Números 16,17 y 18, correspondientes a la primavera, verano y otoño. México, INBA-SEP, 1987.

\section{LIBROS DEL EXTRANJERO}

Coleman, A. D., Manuel Alvarez Bravo. New York, Aperture, Masters of Photography, 1987.

RochFort, DESMond, The Murals of Diego Rivera. "A political chronology" by Julia Engelhardt. London, South Bank Board, 1987.

VARIOS AUTORES, Imagen de México. Catálogo exposición Schirn Kunshalle, Frankfurt, 1987. 